NBER WORKING PAPER SERIES

\title{
DOES TRADE REFORM PROMOTE ECONOMIC GROWTH? A REVIEW OF RECENT EVIDENCE
}

\author{
Douglas A. Irwin \\ Working Paper 25927 \\ http://www.nber.org/papers/w25927
NATIONAL BUREAU OF ECONOMIC RESEARCH
1050 Massachusetts Avenue
Cambridge, MA 02138
June 2019

I thank Chad Bown, Anne Krueger, David Lindauer, Nina Pavcnik, Robert Staiger, and Alan Winters for helpful suggestions. The views expressed herein are those of the author and do not necessarily reflect the views of the National Bureau of Economic Research.

NBER working papers are circulated for discussion and comment purposes. They have not been peer-reviewed or been subject to the review by the NBER Board of Directors that accompanies official NBER publications.

(C) 2019 by Douglas A. Irwin. All rights reserved. Short sections of text, not to exceed two paragraphs, may be quoted without explicit permission provided that full credit, including ()$^{\circ}$ notice, is given to the source. 
Does Trade Reform Promote Economic Growth? A Review of Recent Evidence

Douglas A. Irwin

NBER Working Paper No. 25927

June 2019

JEL No. F13,F14,F43

\begin{abstract}
$\underline{\text { ABSTRACT }}$
Do trade reforms that significantly reduce import barriers lead to faster economic growth? In the two decades since Rodríguez and Rodrik's (2000) critical survey of empirical work on this question, new research has tried to overcome the various methodological problems that have plagued previous attempts to provide a convincing answer. This paper examines three strands of recent work on this issue: cross-country regressions focusing on within-country growth, synthetic control methods on specific reform episodes, and empirical country studies looking at the channels through which lower trade barriers may increase productivity. A consistent finding is that trade reforms have a positive impact on economic growth, on average, although the effect is heterogeneous across countries. Overall, these research findings should temper some of the previous agnosticism about the empirical link between trade reform and economic performance.
\end{abstract}

\author{
Douglas A. Irwin \\ Department of Economics \\ Dartmouth College \\ Hanover, NH 03755 \\ and NBER \\ douglas.irwin@dartmouth.edu
}




\section{Does Trade Reform Promote Economic Growth? A Review of Recent Evidence}

\section{Introduction}

Economists will look back on the decade from 1985 to 1995 as a remarkable period in which developing countries were swept up in a dramatic wave of trade reform that led to much greater openness in the world economy. Did the reduction in import restrictions and other trade barriers pay off in terms of faster growth, greater investment, or higher productivity for the countries that chose this path?

An early set of papers, including Dollar (1992), Sachs and Warner (1995), and Edwards (1998), found support for the idea that openness to trade was associated with better economic outcomes. But these papers were subjected to a wide-ranging critique by Rodríguez and Rodrik (2000, 266), who concluded that "the relationship between trade policy and economic growth remains very much an open question" and "is far from having been settled on empirical grounds." 1

Twenty years have elapsed since Rodríguez and Rodrik last surveyed the field and there are several reasons why this question deserves reexamination. First, many of the early papers had sample periods that ended in the early 1990s, around the time when many big reforms were just being implemented. Any assessment of the impact of these reforms would have been premature at that point, given the length of time it takes to determine if changes in policy have been rewarded with an economic payoff. More recent studies have additional data with which to evaluate the trade reforms undertaken in the late 1980s and early 1990 s.

Second, more countries have undertaken trade reforms, giving us a larger sample of country experiences than were considered in the earlier literature. For example, at the time of

\footnotetext{
${ }^{1}$ Edwards (1993) was equally critical of the research undertaken in the 1970s and 1980s, much of which consisted of country case studies and simple regressions linking exports to growth.
} 
Sachs and Warner (1995), China and India were considered "closed" economies, as were Vietnam, Cambodia, and Bangladesh. Such countries provide additional evidence on the economic consequences of a more open trade regime.

Third, recent work has employed new and varied empirical methods that address many of the concerns raised about earlier studies. Studies have moved away from cross-sectional (between-country) comparisons to looking at within-country growth following a reform episode. These studies have been supplemented with synthetic control methods that allow for a more structured "counterfactual" scenario against which to judge the outcome of reforms. In addition, empirical studies and model-based simulations of particular countries have focused on the channels through which reductions in trade barriers might improve economic performance. These papers often use cross-industry variation in the reduction of trade barriers to identify the impact of increased imports on domestic producers, with a focus on how the reduction in cost and increase in variety of intermediate goods improves the productivity of final goods producers.

This paper reviews recent work on trade reform and economic growth as a way of understanding what progress has been made in uncovering the link between the two. ${ }^{2} \mathrm{~A}$ consistent finding is that trade reforms have a positive impact on economic growth, on average, but as one would expect the effects differ considerably across countries. These results are fairly uniform across methods of analysis, different indicators of trade policy, and other dimensions. The microeconomic evidence that lower tariffs on intermediate goods lead to improved productivity performance of domestic final goods producers is even stronger. Overall, these

${ }^{2}$ Winters and Masters (2013) provide a shorter, less comprehensive review of some of this literature. Other earlier surveys, such as Baldwin (2002) and Winters (2004), focus more on the relationship between "openness" and growth rather than "changes in trade policy" and growth. 
research findings suggest that the outcome of trade reforms can be seen in a more positive light than the agnosticism left in the wake of the Rodríguez and Rodrik critique.

This positive assessment is consistent with recent findings in two different but somewhat related areas of research. First, until recently the consensus among economists was that poorer countries were not growing faster and therefore not catching up to richer countries, although there was evidence in favor of "convergence clubs." Patel, Sandefur, and Subramanian (2018) find strong evidence of unconditional income convergence across countries starting around 1990 but especially since 1995.

Second, research during the 1980s and early 1990s failed to find a significant relationship between policy reform and economic outcomes. The subtitle of Easterly (2001) was "developing countries' stagnation in spite of policy reform." He concluded in Easterly $(2005,1017)$ :

"Although extremely bad policy can probably destroy any chance of growth, it does not follow that good macroeconomic or trade policy alone can create the conditions for high steady state growth."

In updating these previous studies, Easterly (2018) now finds that policy and economic outcomes have improved considerably since the 1990s and are positively correlated. As he puts it: "If the old stylized facts on disappointing growth accompanying reforms led to widespread doubts about the value of economic reforms, the new stylized facts should lead to some more positive updating of such beliefs."

This paper begins by documenting the wave of trade reform that swept the world in the late 1980s and early 1990s. It then looks at the different methods used to assess the links between trade reform and economic performance, including cross-country regressions, synthetic control, and empirical or quantitative country studies, discussing the virtues and vices of each approach. 
The paper focuses on the impact of trade reforms, meaning unilateral reductions in trade barriers; it does not discuss research on several related issues, including the relationship between trade and the level of national income, a question examined by Frankel and Romer (1999), Noguer and Siscart (2005), Feyrer (forthcoming), and others. The general finding of this research is that an exogenous increase in trade has a positive, and potentially large, impact on national income. ${ }^{3}$ However, a policy decision to change trade barriers that leads to an increase in trade may not have the same impact on income as an exogenous increase in trade driven by other factors, such as declining trade costs. This paper does not examine the cross-sectional relationship between the level of trade barriers and economic growth. ${ }^{4}$ The focus is on how changes in a country's own trade barriers (trade liberalization episodes) affect its own economic growth. ${ }^{5}$

This paper does not examine the domestic distributional impact of trade reform, such as the implications for inequality (surveyed by Pavcnik 2017), labor market adjustment (surveyed

\footnotetext{
${ }^{3}$ Rodríguez and Rodrik argue that the Frankel and Romer result is not robust to controlling for omitted variables, such as institutions or distance from the Equator. Feyrer (forthcoming) overcomes this problem by generating a time-varying geographic instrument (based on air versus sea travel). This time-series variation allows controlling for country fixed effects, eliminating the bias from time-invariant variables such as historically determined institutions or distance from the Equator. Trade has a significant effect on income, with an elasticity of roughly one-half (meaning that a 10 percent increase in trade leads to a 5 percent increase in national income). Not all studies have found this result; see, for example, Pascali (2017) on the period 1870-1913, during which only countries with inclusive institutions benefited from increased integration. Other studies assess the gains from increased market access, such as lower transportation costs. Donaldson (2015) surveys this literature, most of which focuses on domestic regional gains from the extension of railroads in India and the United States, the expansion of the highway network in China and the United States, and similar episodes.

${ }^{4}$ Yanikkaya (2003) finds a positive relationship between a country's average tariff and its economic growth for a cross-section of countries for 1970-97. DeJong and Ripoll (2006) look at the same relationship in greater detail. They find a negative relationship for high-income countries and a positive relationship between low-income countries. Nunn and Trefler (2010) document a positive correlation between the skill bias of a country's tariff structure and its long-term growth in per capita income. The positive cross-country relationship between the level of tariffs and economic growth could simply reflect the fact that low-income countries have higher tariffs than highincome countries and have tended to grow faster or that developing countries, despite the higher level of their tariffs, have been reducing them faster than high-income countries and growing faster as a result. Whatever the case, by using the level of tariffs rather than the change in tariffs, these studies are not examining within-country growth as a result of trade reform episodes.

${ }^{5}$ The focus is also on own-country liberalization, not the impact of a foreign market opening on an exporting country.
} 
by McLaren 2017), or the incidence of poverty (surveyed by Winters and Martuscelli 2014). ${ }^{6}$

The paper does not look at the impact of a reduction in trade barriers that come about from free trade agreements (Baier, Yoto, and Zylkin 2019) or regional free trade areas, such as the European Union (Campos, Coricelli, and Moretti 2019).

The evidence in recent studies comes mainly from developing countries and emerging markets rather than from advanced countries. Developing countries have had much higher barriers to trade than advanced countries and have much greater opportunities for catch-up growth, because they are farther behind the technological frontier. While many OECD countries have undertaken trade reforms, sometimes significant ones, over the past few decades, developing countries are where the largest potential payoffs to increased participation in world trade are likely to have been. ${ }^{7}$

\section{The Trade Liberalization Wave in Developing Countries}

From the 1950s and into the 1980s, most developing countries had in place an extensive array of policies that restricted imports (Krueger 1984). These policies went far beyond high import tariffs. They included foreign exchange controls and payment restrictions that

${ }^{6}$ However, the recent paper by Artuc, Porto, and Rijkers (2019) dealing with the tradeoff between the aggregate income gains from trade liberalization and the costs of increased inequality is worth noting in the context of this paper. They calculate the static gains from trade for many countries, look at how it affects household income, and assess the outcome using an Atkinson social welfare function. They find average income gains for 45 countries and average losses for 9 countries, with the static gains amounting to 1.9 percent of average household expenditures (with no accounting for any growth benefits from freer trade). Inequality rises in most countries as a result of trade liberalization, but the income gains typically more than offset the increase in inequality in the social welfare function.

${ }^{7}$ Several OECD countries took significant steps to open further to trade in the 1980s. Australia and New Zealand began scaling back trade protection, and several countries, such as Spain, had to open their markets to more competition when they joined the European Union. On the payoff from these and other reforms, see Prati, Ornorato, and Papageorgiou (2013); Marrazzo and Terzi (2017); and Campos, Coricelli, and Moretti (2019). 
accompanied overvalued currencies; quantitative restrictions, such as import quotas and licenses; and multiple exchange rates.

At various points, countries began to reduce these barriers to trade, often slowly but sometimes rapidly. In some cases, there was a dramatic reorientation of a country's trade regime. Early examples of reforming economies include Taiwan (1958-62), South Korea (1964-68), Chile (1974-79), and a few others. Some countries, such as Brazil (1964-68), Indonesia (196671), and Argentina (1976-82), had brief spells of liberalization followed by a later return to greater restrictions. By 1980, however, the number of reforming countries was still relatively small.

In the late 1980s and early 1990s, however, developing countries embarked on a wave of trade reforms, as many countries moved swiftly to open their markets (Dean, Desai, and Riedel 1994). They often did so by devaluing their currencies and unifying their exchange rates, allowing exporters to retain foreign currency earnings, reducing licensing and quantitative restrictions, and then — often last in the mix — cutting tariffs, usually on intermediate goods first and consumer goods later, sometimes much later.

There are several ways to provide a broad picture of the extensive changes made in this period. Figure 1 shows the number of countries that flipped from being "closed" economies to being "open," according to the classification developed by Sachs and Warner (1995) and extended by Wacziarg and Welch (2008), as discussed below. While there were few reformers in the 1970 s or early 1980 s, the decade after 1985 saw a dramatic increase in the number of countries changing their policies.

Figure 2 presents the average tariff in developed and developing countries. The average tariff in developing countries declined steadily in the 1980s, dropped more sharply in the early 
1990s, and continued to fall at a slower pace thereafter. According to Martin and Ng (2004), the weighted average tariff in developing countries declined from 30 percent in 1983 to 11 percent in 2003. They find that three-quarters of this reduction came from unilateral actions taken by the countries involved; only about 5 percentage points of the decline reflected concession giving in the Uruguay Round negotiations, which took effect starting in $1995 .{ }^{8}$

Figure 3 shows that the reduction in tariffs was not symmetric across regions. South Asian countries, such as India, Bangladesh, and Sri Lanka, started with very high tariffs but reduced them sharply. Latin America and East Asia saw significant reductions as well. By contrast, Africa and the Middle East did not change their policies nearly as much.

One problem with focusing on tariffs is that nontariff barriers have often been a bigger impediment to imports than border duties. Many developing countries have a history of governments allocating foreign exchange to control imports. Exporters were forced to surrender foreign exchange earnings to the central bank, and spending on imports was fixed through a system of import licenses (Bhagwati and Krueger 1973). These foreign exchange controls—often introduced or tightened when countries had overvalued currencies or encountered balance of payments difficulties - are inherently difficult to measure.

Figure 4 presents two indirect indicators of such policies. One shows the share of countries with a nonunified exchange rate (i.e., multiple exchange rates or a parallel market that exists alongside the official rate). It reveals a steady drop from the mid-1980s to the mid-1990s. The other shows the share of countries in which exporters were required to turn over foreign

\footnotetext{
${ }^{8}$ As Finger, Ingco, and Reincke (1996) document, most developing countries did not reduce their applied tariffs as a result of the Uruguay Round. Their concessions amounted to reductions in bound tariffs, which were substantially above their applied tariffs. For example, Argentina increased its number of bound tariffs from 17 percent to 100 percent of all tariff lines. Its average tariff on merchandise was bound at 31 percent, but its applied average tariff was 10 percent. Brazil also increased its tariff bindings, from 16 percent to 100 percent of all tariff lines, but its bound tariff was 29 percent and its applied tariff 12 percent (see Finger, Ingco, and Reincke 1996).
} 
exchange earnings to the government (export surrender requirements), which dropped sharply in the late 1990s.

The World Bank and the International Monetary Fund (IMF) strongly supported these moves by developing countries to open up their markets and seemed confident that there would be a significant payoff from doing so. ${ }^{9}$ Academic economists were more guarded at the time, as reflected in two prominent articles in the Journal of Economic Perspectives. Rodrik $(1992,90)$ argued that the presumption that a liberal trade regime would be good for economic development "is not tremendously helpful for policy at the present time," adding that "in most of the countries that have undertaken radical trade reforms in the 1980s, the direct efficiency consequences of trade liberalization are still uncertain and likely to be small.” Dornbusch $(1992,73)$ welcomed the reform efforts, but noted that "measuring the benefits of trade reform has been a frustrating endeavor. Although the discussion of trade policy at times gives the impression that a liberal trade regime can do wonders for a country's economy, and most observers believe firmly that trade reform is beneficial, yet systematic attempts at quantification fail to single out trade policy as a major factor in economic growth."

Standard theory suggests that reducing trade barriers should lead to efficiency gains. But why might it be expected to increase economic growth as well? The strongest case is that trade reform can promote efficiency in a way that leads to an increase in potential GDP, which leads to an increase in the transitional rate of growth, which is a function of the gap between the current level of GDP and its potential level. The magnitude of the higher transitional growth rate depends on how much the efficiency gains (productivity improvements) or factor accumulation

\footnotetext{
${ }^{9}$ See Edwards (1997), Krueger and Rajapatirana (2003), and Jinjarak, Salinas, and Tsikata (2013) on World Bank support for trade liberalization and Wei and Zhang (2010) for evidence on IMF support for trade liberalization.
} 
(greater investment) increase potential GDP and the length of time it takes for current GDP to converge to potential GDP, both of which differ considerably across countries. When policy reforms (trade related or otherwise) are limited and phased in, there is no reason to expect an immediate burst of growth. But if a country is significantly behind the technological frontier and advanced technologies become available to an economy as a result of new opportunities to trade, some acceleration in growth would be expected.

Suppose trade reform did affect a country's growth rate. How would researchers be able to know it, given the many factors that affect a country's economic growth at the same time? Economists have long recognized that it is exceedingly difficult to isolate individual factors; social scientists cannot run natural experiments in which two countries differ only in their trade policies. To understand the impact of trade policies, they have compiled empirical evidence, identified trade reform episodes in different ways, and made various kinds of counterfactual comparisons.

\section{Cross-Country Regressions}

A seemingly straightforward way to evaluate the impact of a country's trade policy on its economic performance is to compare an outcome variable (growth in real per capita income) under different trade regimes, controlling for as many other covariates as possible. There are many formidable obstacles to doing so, one of which is coming up with a single variable that represents a country's trade policy. ${ }^{10}$ Table 1 summarizes some of the studies reviewed in this section.

${ }^{10}$ Pritchett (1996) shows how various measures of trade policy—tariffs, nontariff barriers, coverage ratios, black-market premiums on foreign exchange markets - are essentially uncorrelated with one another. 
In a widely cited paper, Sachs and Warner (1995) reduce trade policy to a single binary variable. They construct a dummy variable indicating whether a country is "open" or "closed" to trade, defining a country as closed if it had at least one of the following five characteristics: an average tariff of 40 percent or more, nontariff barriers covering 40 percent or more of trade, a black-market exchange rate that was at least 20 percent lower than the official exchange rate, a state monopoly on major exports, or a socialist economic system. Figure 1 shows the number of new countries that became "open" by this tally. Sachs and Warner estimate a simple crosssectional regression

$$
\Delta \log y_{i, 1970-89}=\alpha \log y_{i, 1970}+\gamma \text { Open }_{i, 1980 s}+X \beta+\varepsilon_{i}
$$

that relates economic growth in real per capita income $(y)$ between 1970 and 1989 to the initial level of income in 1970; the openness dummy variable (in the 1980s); and other political and economic control variables, such as schooling rates, investment, and government spending. The estimated coefficient on "open" is 2.4 , implying that open economies grew 2.4 percentage points faster than closed economies. In this regression, the identification comes from comparing open with closed countries, raising the problem of omitted variables, because the two sets of countries could differ on many dimensions the controls do not capture. The results focus on a single-period cross-section; no use is made of the timing of the transitions to openness shown in figure 1. Sachs and Warner thus did not look at the impact of reform episodes on subsequent growth.

Questions were raised about both the dependent and the independent variables. ${ }^{11}$ In terms of the openness dummy variable, the question is whether a simple zero-one indicator accurately characterizes the broad stance of a country's trade policy. Sachs and Warner concede that their

\footnotetext{
${ }^{11}$ The question is whether real per capita GDP is the appropriate measure for the impact of a trade reform. In theory, a tariff reduction should lead to an increase in welfare or real consumption, not necessarily real GDP, which might actually decline, if the changing production mix is evaluated at prereform prices (see Bajona et al. 2010 and Burstein and Cravino 2015).
} 
measure is crude but argue that it usefully places countries into two different and meaningful categories. Winters and Masters $(2013,1062)$ note that "the thresholds are not estimated nor justified, it is not clear which policies really matter and a liberalization is registered only if it flips a country across a threshold." A simple dummy variable does not capture the quantitative significance of a country's trade restrictions or the extent to which a country reforms its policy at a given point in time. ${ }^{12}$ In addition, the variable is unidirectional (from closed to open) and does not capture countries that go through multiple periods of being open or closed. For example, Argentina's trade policy moved in the direction of openness during the 1970s, closed up during the 1980s, opened up again with big reforms starting in 1991, and then began restricting trade again in the 2000 s.

A basic question is which of the five components of the Sachs-Warner measure is most responsible for their empirical findings. Harrison and Hanson (1999) unpack the Sachs-Warner indicator. They find that tariffs and quotas do not have any explanatory power on growth but that exchange rate distortions do. When they try a different tariff measure - the average tariff measured by customs revenues divided by imports - they find that both tariffs and distorted exchange rates have a negative impact on growth. ${ }^{13}$

Rodríguez and Rodrik (2000) argue that the explanatory power of the Sachs-Warner indicator comes mostly from the black-market exchange rate premium and state monopoly of exports. In their view, neither of these factors clearly represents a trade policy variable: State monopoly is effectively a dummy variable for Africa, and a black-market premium is more

\footnotetext{
${ }^{12}$ For example, a country that goes from complete autarky to complete free trade would be represented by the same transition from 0 to 1 as a country that goes from 41 percent tariffs (and other barriers) to 39 percent tariffs (and other barriers).

${ }^{13}$ Sachs and Warner used the average tariff on intermediate goods (gathered from the mid-1980s, the middle of the sample period) collected by the United Nations Conference on Trade and Development (UNCTAD).
} 
reflective of macroeconomic distortions. They conclude that the most direct indicators of trade policy (tariffs and quotas) are not clearly linked to growth outcomes.

Warner (2003) points out that Africa would be categorized as closed even without the state monopoly variable and argues that the black-market premium does not simply represent macroeconomic distortions, as it shows no correlation with inflation. ${ }^{14}$ In fact, an overvalued currency, which a black-market premium reflects, has long been known to be a breeding ground for nontariff import restrictions. The use of trade measures to safeguard the balance of payments and prevent the loss of foreign exchange reserves is a common occurrence in countries that are reluctant to devalue their currencies. There is clear evidence that balance of payments difficulties in countries with overvalued currencies lead them to adopt exchange controls and import compression policies. ${ }^{15}$

The trade reform process often begins with a currency devaluation to eliminate the blackmarket premium. A devaluation stabilizes the loss of foreign exchange reserves and enables the government to end the rationing of foreign exchange, which allows foreign currency to be allocated to its most efficient use. A devaluation also encourages exports and discourages imports, which permits the removal of import licenses and the relaxation of other quantitative import restrictions. Traditional import liberalization—namely, the reduction in import tariffs often occurs later in the reform process.

A shortcoming of the Sachs-Warner analysis is that they do not take advantage of the dates of specific trade reform episodes and investigate whether a move toward more open

${ }^{14}$ The coauthors of the two studies later responded to each other; see Warner (2003) and Rodríguez (2007).

${ }^{15}$ See Shatz and Tarr (2002). Foreign exchange controls have a significant detrimental effect on trade. Wei and Zhang (2007) find that a 1 standard deviation increase in foreign exchange controls has the same effect on trade as a 14 percentage point increase in tariffs. Eichengreen and Irwin (2010) show that during the Great Depression of the 1930s, imports were 23 percent lower in countries imposing exchange controls than in comparable noncontrol countries. 
policies leads to more rapid economic growth. In fact, the Sachs-Warner variable is probably more useful as a marker of the timing of a country's trade reform process than it is as a way of categorizing countries as open or closed. ${ }^{16}$ Instead of comparing growth rates in open versus closed countries, one could examine what happens when a country moves from being closed to being open.

Wacziarg and Welch (2008) examine the within-country effect of trade, updating the Sachs-Warner openness variable to include data from the 1990s (in what will be called the SWWW indicator). They find that the openness variable no longer separates high-growth from low-growth countries the way it could in the 1970s and 1980s. However, they focus on using the dating of reform episodes to estimate the within-country impact of reform on growth and investment through the following regression:

$$
\Delta \log y_{i t}=\alpha+\beta L I B_{i t}+\varepsilon_{i t}
$$

where $y_{i t}$ is per capita income between two periods and LIB is the date of the SWWW liberalization variable, which takes the value of 0 for "closed" economies" and 1 when a country becomes "open" according to the SW criteria. The error term is modeled as $\varepsilon_{i t}=v_{i}+\eta_{t}+\mu_{i t}$, where $v$ reflects country and $\eta$ reflects time fixed effects. The country and time fixed effects mean that the authors do not need to control for other time- and country-specific factors that influence growth.

Wacziarg and Welch find that the within-country estimates of trade reform had a positive, economically large, and statistically significant impact on growth and investment. Over the 1950-98 period, countries that liberalized their trade regimes experienced growth rates that were

${ }^{16}$ One could also raise questions about the particular dates. In commenting on the Sachs and Warner paper, for example, Stanley Fischer questioned the demarcation of Israel as open in 1985, when he believed trade reform occurred in 1963 (Sachs and Warner 1995, 103). 
1.4 percentage point higher than in the prereform period. Wacziarg and Welch also break out the coefficient by decade. The coefficient is 0.6 for $1950-70,1.8$ for $1970-90$, and 2.5 for $1990-98$. The implication is that countries that liberalized in the 1950s and 1960s saw little payoff, but countries that did so in the 1980s and 1990s saw large payoffs. (These results were not driven by two of the largest countries that opened up, China and India, both of which the SWWW indicator still classified as "closed.")

Wacziarg and Welch also examine whether liberalization increases the investment rate and the trade share in GDP. They find that the investment rate rose by 1.5-2.0 percentage points over the prereform period and conclude that about 21 percent of the effect of liberalization on growth came from increased capital investment. They also find that liberalization increased openness (the trade-to-GDP ratio) by nearly 6 percentage points.

Wacziarg and Welch also look at the path of growth around the time of the reform. They find that growth was depressed three years before reform, rose slightly in the three years after reform but was indistinguishable from zero, increased to 1.44 percent in the period three to six years after a reform, and declined to 1.0 percent thereafter. These findings are consistent with a 1.0-1.5 percent increase in growth three years after reform.

Wacziarg and Welch note the high variance in the outcomes: Although the average effect was positive, about half of the countries did not experience more rapid growth after opening. This heterogeneity in outcomes arises from various factors. "Countries that experienced negative or no effects on growth tended to have suffered from political instability, adopted contractionary macroeconomic policies in the aftermath of reforms, or undertaken efforts to counteract trade reforms by shielding domestic sectors from unnecessary adjustments," they note. 
Growth effects could differ markedly across countries for a variety of reasons. The extent that countries undertake reforms could vary significantly in a way that the binary openness variable does not capture. In addition, if complementary reforms, such as freeing the labor market from regulatory restrictions or ensuring greater competition in the service sector, are not undertaken, the gains from trade may be limited. Many factors could impede the success of a reform in bringing about faster growth and exploring this issue seems like a worthwhile area for further research. ${ }^{17}$

One problem with the SWWW dates is that they do not allow for policy reversals-a frequent occurrence in Latin America — and the use of a binary indicator means that the speed and depth of policy changes are not captured. Feyrer and Irwin (2019) expand the SWWW sample to include new liberalizing countries, such as China and India, and allow for the possibility that countries (such as Argentina) go through cycles of liberalization and protectionism. They also employ a continuous time indicator of current account openness (from Quinn 1997) and other measures of trade policy that reflect the speed and depth of such episodes. Looking at the impulse response functions to a change in trade policy, they find that most of the increased growth occurs in the first five years after a reform episode, after which the impact diminishes. For countries going from closed to open, income is about 10 percent higher a decade after the reform.

Another problem in interpreting economic growth after the SWWW dates is that many countries that adopted reform packages also changed many other policies, not just their trade and exchange rate policies, making it difficult to attribute the growth outcomes exclusively to trade

\footnotetext{
${ }^{17}$ Kneller, Morgan, and Kanchanahatakij (2008) explicitly identify some of the big winners and losers from these liberalization episodes, meaning improvement in growth experience before and after reform. Some of the biggest winners were Nicaragua, Guyana, and Mozambique; losers included Guinea-Bissau, the Gambia, and Cape Verde. They do not successfully explain why some countries did well and others did not.
} 
reforms. ${ }^{18}$ To account for this issue, Wacziarg and Welch focus on a subsample of 22 relatively "pure" trade liberalization episodes, mainly developing countries in the 1980s, 8 of which occurred without other major shifts in domestic policy. The results are roughly the same as the results based on the full sample, leading the authors to conclude that it is plausible that the results are in large part attributable to the reform of the external sector.

Prati, Onorato, and Papageorgiou (2013) also try to separate out the contributions of different policies in a reform package to economic performance in a cross-country context. Focusing on the period 1973-2006, they use different indicators for real (trade, agriculture, and networks) and financial (banking, finance, capital account) policy. For trade they use the average tariff and an indicator of current account restrictions, both of which are scaled from 0 to 10 . In the baseline regression, the coefficient on trade is 1.9 and the coefficient on the current account is 3.3 , indicating that both sets of reforms independently improve growth prospects, although it is difficult to interpret the precise meaning of these coefficients.

Other researchers explore the same questions using different indicators of trade reform. ${ }^{19}$ Salinas and Aksoy (2006) take an indicator of trade reform from the World Bank Trade Assistance Evaluation, an ex ante signal of World Bank assistance in helping to initiate a trade

\footnotetext{
${ }^{18}$ As Wacziarg and Welch point out, "It is difficult to attribute differences in growth purely to trade liberalization. Countries carrying out trade reforms often simultaneously adopt policies favoring domestic deregulation, privatization, and other microeconomic reforms and macroeconomic adjustments, making it difficult to interpret the coefficient on liberalization in a within-country regress as the total effect of trade liberalization per se."

${ }^{19}$ Several other regression-based studies deserve brief mention. Based on panel regression, Greenaway, Morgan, and Wright (1998) conclude that 32 countries that reformed after 1985 (identified by Dean, Desai, and Riedel [DDR] 1994) did not have stronger growth than other countries. Greenaway, Morgan, and Wright (2002) published a similar exercise, using a panel of 69 developing countries with several binary indicators (SWWW, DDR, World Bank). All of the indicators had a qualitatively similar result: Reforming countries experienced 2.7 percentage point faster growth, with a two-year lag, than other countries. Using similar methods, Falvey, Foster, and Greenaway (2012) look at whether trade reform that occurs during a crisis (internal versus external) affects its subsequent growth impact. They do not find that a crisis matters much: Liberalization in both crisis and noncrisis periods raised subsequent growth. Falvey, Foster-McGregor, and Khalid (2013) look at the dynamic adjustment of various variables to trade reforms over the period 1970-2005. They find that the impact on the trade share appears after four years and the impact on investment is strongest after seven years.
} 
reform (rather than the SWWW indicator, which might indicate a mid- or postreform period).

The dating marks the start of a trade reform, not the crossing of some arbitrary threshold. ${ }^{20}$ Their variable also includes other countries (such as China, Croatia, and India) that are considered closed by SWWW. They exclude from the sample transition economies, oil exporters, and small countries (countries with fewer than 1 million people), as well as countries with internal conflict. They also rule out years of crises (such as hyperinflation), which they argue artificially reduce the growth rate. After culling, their sample includes 39 countries with nonreversed trade liberalization between 1970 and 2004.

In a cross-country panel regression with country and time fixed effects, they find that the coefficient on the start of a trade reform indicates that economic growth is 1.2 percentage points faster after liberalization than before. Widening the window of the reform period still yields growth that is about 1 percentage point faster. They report that this finding is robust to the inclusion of many other variables that might affect growth, that the results are positive for SubSaharan African countries, and that the reform has no impact on industrialization but does result in a higher fraction of manufactured exports and a reduction in export concentration. Overvalued real exchange rates limit the supply response to trade reform.

Estevadeordal and Taylor (2013) argue that not all tariff reductions should be expected to increase growth: Reducing tariffs on final consumption goods may increase economic welfare, but it would not necessarily increase a country's potential growth in the same way that a reduction in tariffs on capital and intermediate goods could increase the capital stock and improve technology. Consequently, they focus on the differential growth impact of these different tariffs (arguing that broad measures such as average tariffs overall would conflate the

\footnotetext{
${ }^{20}$ Of the 39 reforming countries, the SWWW dates coincide for 25 country years, with most divergences less than three years.
} 
different impacts). They look at a long difference-in-difference regression comparing liberalizing and nonliberalizing countries in two long periods, 1990-2004 and 1975-89, in order to avoid contaminating the results with short-run business cycle fluctuations, crises, or lags in policy implementation.

They start by using an openness indicator variable like SWWW and find that reduced tariffs on capital and intermediate goods resulted in a 1 percentage point growth acceleration for liberalizing countries. They then switch to using data on actual tariff changes, to provide greater variation in policies across countries. The results are stronger for countries that reduced tariffs on intermediate and capital goods than for countries that reduced tariffs only on consumption goods or the overall average tariff. Their key finding is that a 25 percent reduction in the tariff on capital or intermediate goods is associated with a $0.75-1$ percentage point increase in economic growth for liberalizers compared with nonliberalizers. They show a dramatic divergence in the path of real per capita GDP between the two groups: By 2004 the liberalizers were 10 percent above the 1975-98 trend of both and nonliberalizers had fallen almost 10 percent below trend, creating a 15-20 percent gap between the two sets of countries.

Their basic results survive several placebo checks (such as using 1960-75 as the pretreatment period) and the endogeneity of the treatment (the decision to liberalize). They also check to see if the findings are confounded by other policy reforms, such as financial openness, monetary stability, and fiscal stability. They find that the growth acceleration "cannot be attributed to favorable changes in financial openness and macroeconomic policies."

The Estevadeordal and Taylor findings are important because they confirm that using actual tariff data (on intermediate goods) leads to results that are similar to results from the 
SWWW indicator. As the summary in table 1 indicates, either measure of trade reform is associated with about a 1 percentage point increase in economic growth relative to the baseline. A related strand of research examines whether "growth accelerations" are systematically related to economic reform episodes. Hausmann, Pritchett, and Rodrik (2005) identify about 80 episodes of rapid acceleration in economic growth that were sustained for at least eight years during the period $1957-92 .{ }^{21}$ Of many potential factors, they find that accelerations occur when there is an increase in trade, an increase in investment, and a large depreciation in the exchange rate. Using the SWWW dates, they find that although economic reform is a statistically significant predictor of sustained growth accelerations, most instances of economic reform do not produce growth accelerations: Only about 20 percent of sustained growth episodes are preceded or accompanied by economic liberalization, suggesting that many other factors are at work. They conclude that the predictability of growth acceleration episodes is low.

Jong-A-Pin and De Haan (2011) argue that the filter Hausmann, Pritchett, and Rodrik use to select the starting dates of the growth accelerations leads to some anomalous results. ${ }^{22} \mathrm{By}$ simply requiring that economic growth in the first year of the acceleration be higher than the year before, they identify 89 accelerations over the period 1957-93 and report stronger evidence that growth accelerations are preceded by economic liberalization. This result does not depend on the SWWW indicator; it also holds for the Economic Freedom indicator of Gwartney and Lawson (2008). ${ }^{23}$

${ }^{21}$ They define a growth acceleration as meeting three requirements: Growth must be at least 3.5 percent over an eight-year period, growth must be at least 2 percentage points higher than in the previous eight years, and the level of real GDP must be higher at the end of the acceleration than in all years before it.

${ }^{22}$ For example, they point out that the Hausmann, Pritchett, and Rodrik method picks up 27 growth accelerations in which the country experienced higher growth in the year before the start of the acceleration.

${ }^{23}$ They also argue that Hausmann, Pritchett, and Rodrik introduced a coding error in the political regime variable that led to the erroneous conclusion that political regime changes but not economic policy changes lead to growth accelerations. Using another definition of growth acceleration, Peruzzi and Terzi (2018) identify 135 episodes between 1962 and 2002. Using the Giuliano, Mishra, and Spilimbergo (2013) measure of structural reforms 
Related work by Freund and Pierola (2012) uses the SWWW dates as a potential trigger for "export surges." They find that periods of rapid export growth are more likely to occur in open or liberalizing countries, that they are usually preceded by a large depreciation of the real exchange rate, and that new exports (on the extensive margin) account for much of the acceleration. About 58 percent of export surges occurred in open countries or countries that opened within five years before a surge, 24 percent occurred in closed countries, and 19 percent occurred before a country's opening.

In sum, trade liberalization seems related in some way to instances of sustained growth accelerations. Pritchett et al. (2016) document some of the largest and most important growth accelerations (in Taiwan [1962], Brazil [1967], China [1991], India [ 1991], and Poland [1991]), without noting that they seemed to occur around the time of major trade reforms. The magnitude of the gains from these growth accelerations was enormous. The decade-long growth acceleration in India after 1993, for example, amounted to an extra $\$ 1.1$ trillion in national income. Even if more open trade was responsible for just a fraction of the resulting income gains in these cases, trade would have yielded enormous benefits for the countries opening up.

To conclude, a consistent finding of many cross-country regression studies, often using a variant of the SWWW indicator variable, is that countries that reduce high import barriers usually experience a pickup in economic growth. The results may not hold for every country, but on average the results are positive and of an order of magnitude of 1 percentage point or more. While attributing all of the immediate postreform growth to trade policy alone is difficult, researchers have made reasonable, if imperfect, efforts to try to isolate, in a rough way, the impact of trade policy changes from other changes in policy.

(trade, product market, financial sector, etc.), they find that almost 60 percent of growth accelerations were preceded by large changes in economic policy. 
In interpreting the results from such regressions, Winters and Masters (2013) make a critical point: Researchers tend to focus on statistical significance, asking whether we have confidence that an estimated coefficient is different from zero, whereas policymakers care about the distribution of possible outcomes. These are very different questions. They consider the following hypothetical scenario: Suppose a policymaker is considering whether to implement a 10 percentage point tariff reduction when the estimated elasticity of income with respect to the tariff is 1 and the standard error is 0.7 . The null hypothesis that the coefficient is 0 cannot be rejected at the 5 percent confidence level. But for a policymaker, it is much more relevant that 91 percent of the probability mass of outcomes is positive and the best guess is that the tariff reduction would raise income by 10 percent. In virtually all of the papers considered in this section, researchers focused on statistical significance rather than the distribution of outcomes. But in considering the probabilities of various outcomes, the expected value of a trade reform is positive and sometimes quite large.

\section{Synthetic Control Methods}

Focusing on within-country growth as a result of trade liberalization is an improvement over a cross-sectional comparison, but it still does not quite get at the key issue. The sharper counterfactual is not whether growth is faster after a reform episode than before but whether growth performance is stronger than it would have been in the absence of the reform. Answering this question depends on an explicit modeling of what would have happened to an economy had a trade reform not taken place.

Abadie and Gardeazabal (2003) propose a way of setting up a reasonable counterfactual scenario against which a reform episode can be evaluated. A synthetic control is a weighted 
combination of potential comparison countries constructed to fit the prereform economic growth path of the country that undertakes liberalization. This "synthetic" country acts as a control, representing what would have happened to the reforming country had it not reformed. Evaluating the impact of a reform in country $\mathrm{W}$ involves taking a weighted combination of outcomes in nonreforming countries $\mathrm{X}, \mathrm{Y}$, and $\mathrm{Z}$ that match country W's prereform growth path and then comparing the postreform outcomes. This method comes closest in spirit to addressing the problem of finding a counterfactual for what would have occurred in the absence of a reform.

The synthetic control method rests on identification assumptions that are weaker than the assumptions required by estimation techniques commonly used in the trade and growth literature. Panel models, for example, control only for confounding factors that are time invariant (fixed effect) or share a common trend (difference-in-differences). The synthetic control allows the effect of unobservable confounding factors to vary with time.

Billmeier and Nannicini (2013) apply the synthetic control method to 30 trade liberalization episodes from 1963-2005 using the SWWW reform dates. In each case, they choose a set of appropriate comparison countries in which the prereform growth paths in the reforming country and the weighted nonreforming countries are closely matched. The pooled regression-based approaches yield only an average treatment effect across all countries, around which there are successes and failures that are not clearly revealed; the synthetic control approach is essentially a quantitative case study in which each episode constitutes its own individual case.

Billmeier and Nannicini conclude that trade reforms had a positive impact on income, but with much heterogeneity across country and time. This heterogeneity is not surprising and can be attributed to wide differences in the scale of reforms adopted by different countries and whether 
complementary policies (such as labor market reforms) were in place. In general, they find that economic reforms in Asia and Latin America had positive outcomes; growth in real per capita GDP was higher than the counterfactual composite after the reform. Some early reformers in Africa also experienced gains, but that was less true for late reformers. The results were inconclusive for the few reformers in the Middle East and North Africa.

In this approach, no single number quantifies the average impact of trade reform on growth, as each country is a separate case. Indonesia, for example, is presented as an example of an economic liberalization episode (in 1970) that had a large economic payoff. The average income in the years before liberalization was nearly identical to that of the synthetic control, a weighted average of Bangladesh (41 percent), India (23 percent), Nepal (23 percent), and Papua New Guinea (13 percent). After trade reforms, Indonesia's per capita GDP soared. It was 40 percent higher than the estimated counterfactual after five years and 76 percent higher after 10 years. These results are robust to placebo testing, as none of the "fake" experiments for the eight (regional) potential comparison countries showed treatment effects that were larger than the baseline estimates.

This example also illustrates one of the pitfalls of the synthetic control approach. Indonesia is endowed with abundant reserves of petroleum, which became very valuable after the 1973 oil shock, something the synthetic control countries lacked. The posttreatment growth path may thus have been contaminated by factors unrelated to trade reform. ${ }^{24}$

Turning to other Asian countries, South Korea, where trade reforms took effect in 1968, is also deemed a success story, with income about twice as high as in the counterfactual case

${ }^{24}$ Indonesia's economic performance improved dramatically after 1966, when increased growth could not be attributed to high oil prices. According to the SWWW dating method, Indonesia becomes "open" in 1970, although the reform process began in 1966. 
after 10 years. The results are also positive but not as great for the Philippines (1988) and Nepal (1991). In each case, the credibility of the results depends almost entirely on whether the synthetic control is a plausible representation of what would have happened had there been no reform, something that can be judged only on a case-by-case basis.

The results are also generally positive in Latin America. In Barbados, Colombia, Costa Rica, and Mexico, economic outcomes improved after economic liberalization. A decade after liberalization, per capita income was about 57 percent higher in Barbados, 23 percent higher in Colombia, 26 percent higher in Costa Rica, and 21 percent higher in Mexico than in the synthetic control. The placebo tests confirm that these findings are largely robust. Chile turns out to be a particularly hard case to assess, because of the prereform collapse in income and the financial crisis in 1982, which make finding a suitable synthetic control difficult.

The results are more mixed in Africa. Broadly speaking, only the early liberalizations seem to have had a positive impact on per capita income; almost all of the later attempts had only slightly positive or no effects. The authors suggest that the late liberalizers in Africa adopted gradual reform strategies, leading to attenuation bias in the results. In Middle East and North Africa, the results are inconclusive and sometimes the treated countries perform poorly in comparison to a synthetic control.

Billmeier and Nannicini conclude that trade reforms were generally positive and that late liberalizations had a lower payoff or lacked the complementary policies needed to ensure growth. ${ }^{25}$

${ }^{25}$ Marrazzo and Terzi (2017) use a synthetic control approach to examine the impact of 29 structural reform episodes between 1961 and 2000. They find that, on average, reforms had a significant positive impact on per capita GDP, but only after five years. After 10 years, per capita GDP was about 6 percentage points higher than the synthetic counterfactual scenario. However, they consider only reform packages (including trade policy, measured by the average tariff, and other policies together) and cannot quantify the impact of a single policy measure. 
Billmeier and Nannicini (2011) use synthetic control to examine five transition economies from the former Soviet Union: Armenia and Azerbaijan, which liberalized in 1995; Georgia and Tajikistan, which liberalized in 1996; and Uzbekistan, which failed to liberalize. Ten years after liberalization, real per capita GDP was 44 percent higher in Georgia and almost 100 percent higher in Armenia compared with each country's synthetic control. Placebo tests support these results. The results for Azerbaijan were confounded by civil conflict and a drop in natural resource extraction. For Tajikistan no set of countries formed an acceptable synthetic control in which the pretreatment fit was adequate. For the one nonliberalizer, Uzbekistan, the counterfactual synthetic control suggests that real per capita income would have been 75 percent higher had it liberalized trade.

Once again, a big issue affecting the interpretation of these results is whether the SWWW dating marks just a trade reform or a more general market-oriented reform package. If the postreform growth path differs from the synthetic control, the question is whether that divergence is caused by trade reforms or other parts of the reform package. If even a fraction of the income gains can be attributed to the trade component of the reforms, the value of the reform appears to be very large. To the extent the reform package involves a macroeconomic austerity program, such as tighter fiscal and monetary policies, one might expect growth performance to have been worse in the short run.

\section{Channels of Impact: Tariffs on Intermediate Goods}

Rodríguez and Rodrik (2000) suggested that the search for a general empirical relationship between trade policy and economic growth was "futile." They were more hopeful that microeconomic evidence could reveal the channels by which trade policy might affect 
productivity at the industry or firm level. An important body of microeconomic research has made significant progress on this question over the past 20 years. ${ }^{26}$

The increased availability of firm-level data in developing countries has allowed researchers to determine the economic adjustments that were made in the wake of trade reforms or the opening of export opportunities. One benefit of this approach is that it does not rely on an aggregate indicator variable as a measure of trade policy or the single-year dating of a trade reform. Instead, specific measures, such as tariffs, yield detailed information on the variation in protection levels across different sectors of the economy and how those barriers changed over time, creating a measure of differential exposure to foreign competition across industries. This tariff variation helps identify the effects of lower import barriers (on such outcome variables as output or labor productivity), as there are multiple margins on which trade policy measures differ across sectors (such as the initial height of the tariffs and the differential speed with which tariffs are reduced).

This approach requires detailed investigation of one country, at the cost of not necessarily being able to generalize the results across countries. In addition, the firm- or industry-level outcome variables, such as productivity, can be difficult to measure. For example, a standard method has been to estimate a production function (using revenue deflated by a price index as a proxy for output) and treat as total factor productivity the difference (residual) between actual and estimated production (based on capital, labor, and material inputs). De Loecker (2011) argues there may be a spurious relationship between this way of measuring productivity and openness to trade, given the impact of policy changes on prices and demand but that new methods have improved upon past practices.

${ }^{26}$ For a recent survey, see De Loecker and Van Biesebroeck (2018). 
Most of this literature focuses on whether lower tariffs (on both intermediate goods and final goods) lead to within-industry efficiency gains as domestic producers face intensified competition. ${ }^{27}$ A reduction in trade barriers could improve productivity in two ways. First, greater head-on competition forces firms to become more efficient and reduce their costs to compete in the same market. Second, increased trade in intermediate goods gives domestic purchasing firms access to a wider array of less expensive intermediate goods that they can use to produce final goods. The increased availability of intermediate goods can affect final goods producers through lower prices, increased quality, and increased variety of inputs, all of which improve efficiency. The improved productivity of final goods producers as a result of the reduction in tariffs on intermediate goods has been a primary focus of this work. ${ }^{28}$

Table 2 summarizes a few of the studies in this area. Pavcnik (2002) examines the response of Chilean manufacturing to increased competition in 1979-86 to document the productivity effects arising from a reduction in import barriers. She compares sectors facing liberalized trade (import-competing and export-oriented sectors) to the nontraded-goods sector in order to distinguish the productivity effects stemming from more open trade from other sources. She finds that the productivity of plants in import-competing sectors grew 3-10 percent faster than in nontraded-goods sectors. Greater competition was presumably the source of these

\footnotetext{
${ }^{27}$ Several papers document the consumer gains from lower tariffs on final goods. Tovar (2012) examines the reduction in Colombia's tariff on automobiles. He finds consumer gains of about $\$ 3,000$ per vehicle. Sheu (2014) studies the gradual elimination of the 20 percent tariff on imported printers in India, which resulted in a large increase in imports. She disentangles three factors - lower prices, higher quality, and greater variety — all of which could boost consumer welfare. She finds that the higher quality of imports was the most important factor in generating gains from trade. The contribution of price was slightly smaller; variety lagged farther behind. The strength of these effects varied across buyers, with gains largest for small businesses.

${ }^{28}$ Feenstra, Markusen, and Zeile (1992) discuss the theory that access to new intermediate goods and cheaper existing goods can lead to higher productivity in the production of final goods. Most research is unable to directly measure the adoption of new technology as a result of trade. One exception is Bustos (2011), who studies the impact of Brazilian tariff reductions on Argentine exporting firms. She finds that Argentine firms in industries facing greater reductions in Brazil's tariffs increased investment in technology faster than firms facing smaller tariff reductions. This situation is different from looking at the impact of changes in Argentinian trade policy on firms in Argentina; it looks at export market access rather than the effect of changing a country's own import policy.
} 
productivity gains, although much of the increase came from the forced exit of existing plants, which were about 8 percent less productive on average than the plants that continued to produce.

In a similar vein, Fernandes (2007) examines a period of substantial variation in protection across manufacturing industries in Colombia (1977-91) to see whether increased exposure to foreign competition generated productivity gains. She finds a strong positive impact of tariff liberalization on plant productivity, even after controlling for plant and industry heterogeneity, real exchange rates, and cyclical effects. Productivity improvements under trade liberalization are linked to increases in imports of intermediate inputs, skill intensity, and machinery investments and to reallocations of output from less to more productive plants. The impact was stronger for plants in industries initially facing less competition.

Brazil has been another country of focus, with some divergent results using firm-level data. ${ }^{29}$ Muendler (2004) finds evidence that the pressure of foreign competition raised manufacturing productivity markedly but that the use of foreign inputs played only a minor role in productivity change. Schor (2004) reports that increased exposure to competition led to productivity improvements but that access to new inputs embodying better foreign technology also contributed to productivity gains.

More refined data on the use of imported intermediate goods have allowed researchers to trace that channel more clearly. Amiti and Konings (2007) use plant-level data on imported inputs from Indonesia during 1991-2001. They find that the largest productivity gains arise from lower input tariffs: A 10 percentage point reduction in input tariffs led to a 12 percent productivity gain for importing firms; the productivity gain associated with a 10 percentage point reduction in output tariffs was $1-6$ percent. Although it is not possible to determine the precise

\footnotetext{
${ }^{29}$ At the industry level, Ferreira and Rossi (2003) estimate that Brazil's early liberalization, in 1988-90, led to a 6 percent increase in the growth rate of total factor productivity and had a similar impact on labor productivity.
} 
channel that gives rise to this higher productivity, the large impact for importing firms compared with nonimporting firms suggests that direct benefits may accrue from the technology embodied in the imported inputs. ${ }^{30}$

Using data from Chile, Kasahara and Rodrigue (2008) determine that a plant can immediately improve productivity by switching from being a nonimporter to being an importer of foreign intermediate goods. Although the point estimates differ across estimators, even the within-group estimate, which they suspect is downward biased, indicates a 2.6 percent positive productivity effect from importing. They also find some evidence of a positive dynamic effect from the use of imported materials.

Several detailed studies look at India's trade reforms in 1991. Topalova and Khandelwal (2011) use the variation in liberalization across sectors to evaluate the effect of reforms on firmlevel productivity. They find that reduced tariffs increased competition in general and forced firms facing that competition to improve their efficiency. Reduced tariffs on imported inputs increased their availability, making their purchasers more efficient. The availability of cheaper inputs was a more significant driver of productivity than increased final goods competition.

For India's trade policy changes between 1989 and 1996, the cuts in final goods tariffs accounted for a 1.7 percent increase in productivity, and the cuts in intermediate goods tariffs accounted for a 10.6 percent increase in productivity. The impact on productivity of lower input tariffs was thus greater than the pro-competitive effects of lower final goods tariffs. Firms in heavily regulated industries did not enjoy productivity benefits, either because they did not

${ }^{30}$ Similar effects have been found in more advanced economies. Halpern, Koren, and Szeidl (2015) investigate the effect of imported inputs on productivity using microdata from importers in Hungary. They find that importing all input varieties would increase a firm's revenue productivity by 22 percent, with about half of the increase arising from imperfect substitution between foreign and domestic inputs. They attribute one-quarter of Hungary's productivity growth over the 1993-2002 period to increased imports of intermediate goods. 
respond to competitive pressure or because they lacked the freedom to adjust their production technology after the reforms.

Goldberg et al. (2010) link the decline in India's input tariffs to an expansion in a downstream firm's product scope, finding that industries experiencing the greatest decline in input tariffs introduced more new products. Lower input tariffs accounted for a third of the observed increase in firms' product scope. They also improved firm performance, measured by output, total factor productivity, or research and development spending. The authors separate changes into a "price" and a "variety" channel and find substantial gains from access to new varieties of imported inputs. Accounting for new imported varieties lowers the import price index for intermediate goods by an additional 4.7 percent a year beyond the conventional gains through lower prices of existing imports. The availability of more varieties relaxed the technological constraints facing producers, who were able to source new and better inputs that were not available before liberalization.

Other papers focus on China, another big reforming country. Brandt et al. (2017) examine China's tariff reductions as it sought entry into the World Trade Organization (WTO) in the midto late 1990s. They find that lower tariffs increased competition in the industry directly facing foreign competition. Their point estimate of this effect in China is similar to that estimated for India: Each percentage point reduction in output tariffs lowered markups by $0.10-0.15 \log$ points. In particular, state-owned firms were forced to improve their efficiency (and reduce markups) to avoid bankruptcy when faced with increased competition. The pro-competitive effects were most important among incumbents. New entrants were poised to achieve greater efficiency gains. Brandt et al. show that lower input tariffs increased efficiency in downstream 
purchasing industries, with a 1 percentage point lower tariffs on inputs reducing output prices by 1.6 percent.

Lower input tariffs have also been found to reduce the costs of domestic producers in a way that increases exports. Using detailed firm-level data from Argentina, Bas (2012) finds that the probability of entering the export market was higher for firms producing in industries that experienced greater input tariff reductions. Amiti et al. (2017) exploit the cross-industry variation in trade liberalization in China. They find that lower input tariffs reduced the costs to purchasers, boosting Chinese firms' productivity and their exports.

In sum, while reducing tariffs on final goods increases the pressure of competition on domestic producers to improve their productivity, a growing body of evidence points to the benefits of reducing tariffs on intermediate goods and other inputs. Domestic producers benefit from lower prices, improved quality, and greater variety of imported inputs, all of which help them improve their productivity performance. ${ }^{31}$

Unfortunately, this literature has not succeeded in providing an aggregate or economywide measure of the productivity improvement resulting from this channel. While improved productivity performance in manufacturing is an important driver of overall productivity in many developing countries, the contribution of trade openness at the aggregate level has yet to be established. There is still debate about the role of trade in expanding or shrinking the size of the manufacturing sector in developing countries. The benefits of achieving greater productivity in labor-abundant countries that export manufactured goods have been readily apparent. In contrast, for developing countries that export natural resources or agricultural goods, an increase in openness to trade could shrink the overall size of the

\footnotetext{
${ }^{31}$ Other studies have focused on the positive productivity effects emanating from trade reforms in Mexico (Luong 2011), Vietnam (Ha 2015), and Uruguay (Casacuberta and Zaclicever 2016). The results are broadly similar.
} 
manufacturing sector. If it does, aggregate productivity growth could fall, because improvements in firm-level productivity would be offset by a decline in the size of the manufacturing sector.

\section{Qualitative and Quantitative Country Studies}

A perennial problem with empirical evidence, particularly across countries, is that questions can always be raised about the quality of the data, the method of analysis, the robustness of the results, and so forth. Srinivasan and Bhagwati (2001) go so far as to reject all cross-country regression methods, arguing that the most compelling evidence on the consequences of trade reform can come only from careful case studies of policy regimes in different countries.

There have been several multivolume country studies of trade reform and the lessons to be derived therefrom. In the late 1960s, the Organization for Economic Cooperation and Development (OECD) sponsored a series of books on trade policy and industrialization in selected developing countries. The two most famous volumes to emerge from that effort were Bhagwati and Desai's book India: Planning for Industrialization and Little, Scitovsky, and Scott's summary volume Industry and Trade in Some Developing Countries, both published in 1970. In the early 1970s, the National Bureau of Economic Research (NBER) published a series of studies on foreign trade regimes and economic development, along with two summary volumes, by Bhagwati (1978) and Krueger (1978). Both the OECD and NBER studies documented the costs of inward-oriented, import substitution trade regimes and the benefits of outward-oriented, export promotion policies. ${ }^{32}$

${ }^{32}$ At the World Bank, Belassa $(1982,57)$ also looked at country case studies of the early reformers in the 1960s and 1970s. He concluded that "trade orientation has been an important factor contributing to intercountry differences in the growth of income." 
In 1991 the World Bank published the seven-volume series Liberalizing Foreign Trade, which covers 36 liberalization episodes in 19 countries over 1950-84 (the only reformers from the 1980s were Turkey and New Zealand). The overview volume, by Papageorgiou, Choksi, and Michaely $(1990,41)$ confidently reported that "[trade] reform can work anywhere, regardless of initially unfavorable circumstances, and without serious short-term drawbacks. Governments with highly distorted trade regimes need not fear the consequences of a well-designed liberalization program."

This massive effort was very informative and provided an abundance of detail on different reform episodes. But such sweeping conclusions drew criticism. Greenaway (1993) argued that "the conviction with which the conclusions are reported is misleading" and stated that the narrative approach led to "impressionistic" conclusions about the consequences of various trade policies, because it was hard to disentangle the impact of trade policies from other policies pursued at the same time. Collier (1993) lamented the lack of any analytical framework guiding the World Bank effort and feared that the sample of countries chosen was small and not random. He also worried that "there seem to be few simple empirical regularities" because every country seemed to have its own path and face its own difficulties, making broad generalizations difficult. ${ }^{33}$

The qualitative nature of the country-study approach has often provided useful information, but it has never been entirely satisfactory to most economists. It seems to have fallen out of favor, as there was no major attempt to provide a complete record of reforms

${ }^{33}$ The World Bank also published a summary volume on macroeconomic adjustment (Little et al. 1993) that touches on some trade reforms in the 1980s. 
between the late 1980s and the early 1990s. ${ }^{34}$ The OECD, NBER, and World Bank studies deal mainly with trade reform undertaken in the 1960s and 1970s.

Of greater interest to economists are quantitative country studies based on detailed structural models. These models can be built for a particular country, calibrated to match country data for a prereform year, and then used to simulate counterfactual scenarios in which particular policies are adjusted to understand their impact on various economic outcomes. There are only a few examples of such studies, because conducting them requires a relatively large investment that yields information for only one country, raising questions of external validity.

The best example of this type of research is the Connolly and Yi (2015) study of South Korea. South Korea moved from economic isolation (caused in part by heavy protection) to export promotion in the mid-1960s. Exports as a share of GDP rose from 2 percent in 1962 to 30 percent in less than two decades, and its growth experience has been miraculous. But the Korean case is also controversial because there is a debate about the contribution of trade policy to its growth performance and whether industrial policy and other factors played a significant role. ${ }^{35}$

To help untangle the role of trade policy, Connolly and Yi develop a two-sector neoclassical growth model, calibrated with Korean data, to simulate the trade policy changes that occurred between early 1962 and 1989. The model can explain almost all of Korea's trade growth and most of its increase in imports of investment goods. They then examine three distinct trade policy changes: (a) the elimination of tariffs on intermediate goods and capital equipment for goods produced for export in the mid-1960s, (b) the reduction in general tariffs from about 40

\footnotetext{
${ }^{34}$ One incomplete effort, focused more on the political economy of the reforms than their economic consequences, is Williamson (1994).

${ }^{35}$ For example, Westphal (1990) argues that "import liberalization was not an important element of the reforms that put Korea on the path of export-led development." It is unclear whether his statement included the liberalization of intermediate goods or referred only to liberalization of final goods. The latter is certainly true in the 1960s and 1970s; the former would certainly be contested. For a recent survey of new work on industrial policy, see Lane (2019).
} 
percent in early 1970s to about 13 percent by 1989, and (c) the reduction in foreign tariffs on Korean exports as a result of the Kennedy and Tokyo Rounds of the General Agreement on Tariffs and Trade (GATT) in the 1960s and 1970s. Taken together, their model suggests that these tariff reductions can explain 17 percent of South Korea's catch-up to advanced countries in value added per worker in the manufacturing sector. Although more than 80 percent of the catchup is left unexplained, trade policies alone account for a sizable share of the productivity improvement. In addition, trade reforms account for a 19 percent increase in consumption per worker (their measure of welfare).

Two transmission channels - multistage production and imported investment goodsdrive these efficiency gains, as well as most of the welfare gains. Connolly and Yi argue that the results from their neoclassical growth model constitute a lower bound on the contribution of trade policy reform to Korea's growth miracle, because it does not address other mechanisms by which trade could affect growth, such as learning or technological spillovers that enhanced through exporting and importing activities or the impact on human capital formation. The model also does not allow them to examine factors such as industrial policies and credit subsidies. ${ }^{36}$

External validity is always a question: What happened to South Korea might not be expected to happen in Cameroon. Unless other economists create such models for other countries, it will not be possible to know how trade reform affects economic structure and performance in different contexts. Nevertheless, the detailed approach of Connolly and Yi in the setting of one country helps separate the contributions of particular reforms to economic outcomes and is a useful alternative to a simple indicator variable in a multicounty regression.

\footnotetext{
${ }^{36}$ Betts, Giri, and Verma (2017) develop a model of Korea to examine structural change but do not directly address trade policy.
} 


\section{Conclusion}

Economists have been interested in the relationship between trade restrictions and economic growth since the time of Adam Smith. The great trade reform wave of the late 1980s and early 1990s provides new historical evidence on the matter. There is no one perfect method that can provide decisive evidence on this question, so researchers have tried to understand the relationship using a variety of approaches.

The findings from recent research have been remarkably consistent. For developing countries that are behind the technological frontier and have significant import restrictions, there appears to be a measurable economic payoff from more liberal trade policies. As table 1 reports, a variety of studies using different measures of policy have found that economic growth is roughly $1.0-1.5$ percentage points higher than a benchmark after trade reform. Several studies suggest that this gain cumulated to about 10-20 percent higher income after a decade. The effect is heterogeneous across countries, because countries differ in the extent of their reforms and the context in which reform took place.

At a microeconomic level, the gains in industry productivity from reducing tariffs on imported intermediate goods are even more sharply identified. They show up time and again in country after country.

Some questions remain about how much of the economic growth following trade reform can be attributed to trade policy changes alone, as other market reforms are sometimes adopted at the same time. Even if the reduction of trade barriers accounts for only a part of the observed increase in growth, however, the cumulative gains from reform appear to be substantial. As Estevadeordal and Taylor $(2013,1689)$ ask, "Is there any other single policy prescription of the 
past twenty years that can be argued to have contributed between 15 percent and 20 percent to developing country income?" 


\section{References}

Abadie, Alberto, and J. Gardeazabal, 2003. The Economic Costs of Conflict: A Case Study of the Basque Country. American Economic Review 93: 113-132.

Amiti, Mary, Mi Dai, Robert C. Feenstra, and John Romalis. 2017. How Did China's WTO Entry Affect U.S. Prices? NBER Working Paper 23487. Cambridge, MA: National Bureau of Economic Research.

Amiti, Mary, and Jozef Konings. 2007. Trade Liberalization, Intermediate Inputs, and Productivity: Evidence from Indonesia. American Economic Review 97: 1611-38.

Artuc, Erhan, Bob Rijkers, and Guido Porto. 2019. "Trading Off the Income Gains and the Inequality Costs of Trade Policy.” World Bank Policy Research Working Paper 8825.

Baier, Scott L., V. Yotov Yoto, and Thomas Zylkin. 2019. On the Widely Differing Effects of Free Trade Agreements: Lessons from Twenty Years of Trade Integration. Journal of International Economics 116: 206-26.

Bajona, Claustre, Mark J. Gibson, Timothy J. Kehoe, and Kim J. Ruhl. 2010. Trade Liberalization, Growth, and Productivity. Working paper. Minneapolis: University of Minnesota.

Baldwin, Robert E. 2002. Openness and Growth: What's the Empirical Relationship? In Challenges to Globalization: Analyzing the Economics, ed. Robert E. Baldwin and L. Alan Winters. Chicago: University of Chicago Press.

Bas, Maria. 2012. Input-Trade Liberalization and Firm Export Decisions: Evidence from Argentina. Journal of Development Economics 97: 481-93.

Belassa, Bela. 1982. Development Strategies in Semi-industrial Countries. Baltimore: Johns Hopkins Press for the World Bank.

Betts, Caroline, Rahul Giri, and Rubina Verma. 2017. Trade, Reform, and Structural Transformation in South Korea. IMF Economic Review 65: 745-91.

Bhagwati, Jagdish. 1978. Anatomy and Consequences of Exchange Control Regimes. Cambridge, MA: Ballinger for the National Bureau of Economic Research.

Bhagwati, Jagdish N., and Padma Desai. 1970. India: Planning for Industrialization. New York: Oxford University Press for the Organization for Economic Cooperation and Development. 
Bhagwati, Jagdish N., and Anne O. Krueger. 1973. Exchange Control, Liberalization, and Economic Development. American Economic Review 63: 419-27.

Billmeier, Andreas, and Tommaso Nannicini. 2011. Economies in Transition: How Important Is Trade Openness for Growth? Oxford Bulletin of Economics and Statistics 73: 287-314. Billmeier, Andreas, and Tommaso Nannicini. 2013. Assessing Economic Liberalization Episodes: A Synthetic Control Approach. Review of Economics and Statistics 95: 9831001.

Brandt, Loren, Johannes Van Biesebroeck, Luhang Wang, and Yifan Zhang. 2017. WTO Accession and Performance of Chinese Manufacturing Firms. American Economic Review 107: 2784-820.

Burstein, Ariel, and Javier Cravino. 2015. Measured Aggregate Gains from International Trade. American Economic Journal: Macroeconomics 7: 181-218.

Bustos, Paula. 2011. Trade Liberalization, Exports and Technology Upgrading: Evidence on the Impact of MERCOSUR on Argentinean Firms. American Economic Review 101: 304-40.

Campos, Nauro F., Fabrizio Coricelli, and Luigi Moretti. 2019. Institutional Integration and Economic Growth in Europe. Journal of Monetary Economics 103: 88-104.

Casacuberta, Carlos, and Dayna Zaclicever. 2016. The Effect of Input and Output Protection on Productivity in Uruguay. Universidad de la República Uruguay. Photocopy.

Collier, Paul. 1993. Higgledy-Piggledy Liberalisation. World Economy 16: 503-11.

Connolly, Michelle, and K. Yi. 2015. How Much of South Korea’s Growth Miracle Can Be Explained by Trade Policy? American Economic Journal: Macroeconomics 7: 188-221.

Dean, Judith M., S. Desai, and James Riedel. 1994. Trade Policy Reform in Developing Countries since 1985: A Review of the Evidence. World Bank Discussion Paper 267. Washington: World Bank.

DeJong, David N., and Maria Ripoll. 2006. Tariffs and Growth: An Empirical Exploration of Contingent Relationships. Review of Economics and Statistics 88: 625-40.

De Loecker, Jan. 2011. Product Differentiation, Multi-Product Firms and Estimating the Impact of Trade Liberalization on Productivity. Econometrica 79: 1407-51.

De Loecker, Jan, and Johannes Van Biesebroeck. 2018. Effect of International Competition on Firm Productivity and Market Power. Oxford Handbook of Productivity Analysis, ed. 
Emili Grifell-Tatjé, C. A. Knox Lovell, and Robin C. Sickles. New York: Oxford University Press.

Dollar, David. 1992. Outward-Oriented Developing Economies Really Do Grow More Rapidly: Evidence from 95 LDCs, 1976-1985. Economic Development and Cultural Change 40: $523-44$.

Donaldson, Dave. 2015. The Gains from Market Integration. Annual Review of Economics 7: $619-47$.

Dornbusch, Rudiger. 1992. The Case for Trade Liberalization in Developing Countries. Journal of Economic Perspectives 6: 69-85.

Easterly, William. 2001. The Lost Decades: Developing Countries' Stagnation in Spite of Policy Reform 1980-1998. Journal of Economic Growth 6: 135-57.

Easterly, William. 2005. National Economic Policies and Economic Growth: A Reappraisal. Handbook of Economic Growth, vol. 1A., ed. Philippe Aghion and Steven N. Durlauf. Amsterdam: North-Holland.

Easterly, William. 2018. In Search of Reforms for Growth: New Stylized Facts on Policy and Growth Outcomes. New York University. Photocopy.

Edwards, Sebastian. 1993. Openness, Trade Liberalization, and Growth in Developing Countries. Journal of Economic Literature 31: 1358-93.

Edwards, Sebastian. 1997. Trade Liberalization Reforms and the World Bank. American Economic Review 87: 43-48.

Edwards, Sebastian. 1998. Openness, Productivity, and Growth: What Do We Really Know? Economic Journal 108: 383-98.

Eichengreen, Barry, and Douglas A. Irwin. 2010. The Slide to Protectionism in the Great Depression: Who Succumbed and Why? Journal of Economic History 780: 871-97.

Estevadeordal, Antoni, and Alan M. Taylor. 2013. Is the Washington Consensus Dead? Growth, Openness, and the Great Liberalization, 1970s-2000s. Review of Economics and Statistics 95: 1669-90.

Falvey, Rod, Neil Foster, and David Greenaway. 2012. Trade Liberalization, Economic Crisis, and Growth. World Development 40: 2177-93.

Falvey, Rod, Neil Foster-McGregor, and Ahmed Khalid. 2013. Trade Liberalization and Growth: A Threshold Analysis. Journal of the Asia Pacific Economy 18: 230-52. 
Feenstra, Robert C., James R. Markusen, and William Zeile. 1992. Accounting for Growth with New Inputs: Theory and Evidence. American Economic Review 82: 415-21.

Fernandes, Ana. 2007. Trade Policy, Trade Volumes and Plant-level Productivity in Colombian Manufacturing Industries. Journal of International Economics 71: 51-72.

Ferreira, Pedro Cavalcanti, and José Luiz Rossi. 2003. New Evidence from Brazil on Trade Liberalization and Productivity Growth. International Economic Review 44: 1383-405.

Feyrer, James. Forthcoming. Trade and Income: Exploiting Time Series in Geography. American Economic Journal: Applied Economics.

Feyrer, James, and Douglas A. Irwin. 2019. Trade Policy Reform and Economic Growth Revisited. Working Paper. Hanover, NH: Dartmouth College.

Finger, J. Michael, Merlinda D. Ingco, and Ulrich Reincke. 1996. The Uruguay Round: Statistics on Tariff Concessions Given and Received. Washington: World Bank.

Frankel, Jeffrey A., and David Romer. 1999. Does Trade Cause Growth? American Economic Review 89: 379-99.

Freund, Caroline, and Martha Denisse Pierola. 2013. Export Surges. Journal of Development Economics 97: 387-95.

Giuliano, Paolo, Prachi Mishra, and Antonio Spilimbergo. 2013. Democracy and Reforms: Evidence from a New Dataset. American Economic Journal: Macroeconomics 5: 179204.

Goldberg, Penelopi, Amit Khandelwal, Nina Pavcnik, and Petia Topalova. 2010. Imported Intermediate Inputs and Domestic Product Growth: Evidence from India. Quarterly Journal of Economics 125: 1727-67.

Greenaway, David. 1993. Liberalising Trade through Rose-Tinted Glasses. Economic Journal 103: 208-22.

Greenway, David, C. Wyn Morgan, and Peter Wright. 1998. Trade Reform, Adjustment and Growth: What Does the Evidence Tell Us? Economic Journal 108: 1547-61.

Greenway, David, C. Wyn Morgan, and Peter Wright. 2002. Trade Liberalisation and Growth in Developing Countries. Journal of Development Economics 67, no. 1: 229-44.

Gwartney, James, and Robert Lawson. 2008. Economic Freedom of the World: Annual Report. Vancouver: Fraser Institute. 
Ha, Doan Thi Thanh. 2015. Trade Liberalization, Product Differentiation and Firm Productivity:

Evidence from Vietnam. Yokohama National University. Photocopy.

Halpern, László, Miklós Koren, and Adam Szeidl. 2015. Imported Inputs and Productivity. American Economic Review 105: 3660-703.

Harrison, Ann, and Gordon Hanson. 1999. Who Gains from Trade Reform? Some Remaining Puzzles. Journal of Development Economics 59: 125-54.

Hausmann, Ricardo, Lant Pritchett, and Dani Rodrik. 2005. Growth Accelerations. Journal of Economic Growth 10: 303-29.

Ilzetzki, Ethan, Carmen M. Reinhart, and Kenneth S. Rogoff. 2017. Exchange Arrangements Entering the 21st Century: Which Anchor Will Hold? NBER Working Paper 23134. Cambridge, MA: National Bureau of Economic Research.

IMF (International Monetary Fund). Various years. Annual Report on Exchange Restrictions and Exchange Arrangements. Washington: IMF.

Jinjarak, Yothin, Gonzalo Salinas, and Yvonne M. Tsikata. 2013. The Effect of World Bank Trade Adjustment Assistance on Trade and Growth, 1987-2004: Is the Glass Half Full or Half Empty? Economic Systems 37: 415-30.

Jong-A-Pin, Richard, and Jakob De Haan. 2011. Political Regime Change, Economic Liberalization, and Growth Accelerations. Public Choice 146: 93-115.

Kasahara, Hiroyuki, and Joel Rodrigue. 2008. Does the Use of Imported Intermediates Increase Productivity? Plant-level Evidence. Journal of Development Economics 87: 106-18.

Kneller, Richard, C. W. Morgan, and Sunti Kanchanahatakij. 2008. Trade Liberalisation and Economic Growth. World Economy 31: 701-19.

Krueger, Anne O. 1978. Liberalization Attempts and Consequences. Cambridge: Ballinger for the National Bureau of Economic Research.

Krueger, Anne O. 1984. Trade Policies in Developing Countries. In Handbook of International Economics, vol. 1, ed. Ronald Jones and Peter Kenen. Amsterdam: North Holland.

Krueger, Anne O., and Sarath Rajapatirana. 2003. World Bank Policies toward Trade and Trade Policy Reform. World Economy 22: 717-40.

Lane, Nathaniel. 2019. The New Empirics of Industrial Policy. Monash University. Photocopy. Little, Ian, Tibor Scitovsky, and Maurice Scott. 1970. Industry and Trade in Some Developing Countries. Oxford: Oxford University Press. 
Little, I.M.D., Richard N. Cooper, W. Max Corden, and Sarath Rajapatirana. 1993. Boom, Crisis, and Adjustment: The Macroeconomic Experience of Developing Countries. New York: Oxford University Press for the World Bank.

Luong, Tuan Anh. 2011. The Impact of Input and Output Tariffs on Firms' Productivity: Theory and Evidence. Review of International Economics 19: 821-35.

Marrazzo, Pasquale Marco, and Alessio Terzi. 2017. Wide-Reaching Structural Reforms and Growth: A Cross-Country Synthetic Control Approach. Center for International Development Working Paper 82. Cambridge, MA: Harvard University.

Martin, Will, and Francis Ng. 2004. A Note on Sources of Tariff Reductions in Developing Countries 1983-2003. Washington: World Bank.

McLaren, John. 2017. Globalization and Labor Market Dynamics. Annual Review of Economics 9: $177-200$.

Muendler, Marc-Andreas. 2004. Trade, Technology, and Productivity: A Study of Brazilian Manufacturers, 1986-1998. Working paper. San Diego: University of California.

Noguer, Marta, and Marc Siscart. 2005. Trade Raises Income: A Precise and Robust Result. Journal of International Economics 65: 447-60.

Nunn, Nathan, and Daniel Trefler. 2010. The Structure of Tariffs and Long-Term Growth. American Economic Journal: Macroeconomics 2: 158-94.

Papageorgiou, Demetrios, Armeane M. Choksi, and Michael Michaely. 1990. Liberalizing Foreign Trade in Developing Countries: The Lessons of Experience. Washington: World Bank.

Pascali, Luigi. 2017. The Wind of Change: Maritime Technology, Trade, and Economic Development. American Economic Review 107: 2821-54.

Patel, Dev, Justin Sandefur, and Arvind Subramanian. 2018. Everything You Know about CrossCountry Convergence Is Wrong. October 15. Washington: Center for Global Development. https: //www.cgdev.org/blog/everything-you-know-about-cross-countryconvergence-now-wrong.

Pavcnik, Nina. 2002. Trade Liberalization, Exit, and Productivity Improvements: Evidence from Chilean Plants. Review of Economic Studies 69: 245-76.

Pavcnik, Nina. 2017. The Impact of Trade on Inequality in Developing Countries. NBER Working Paper 23878. Cambridge, MA: National Bureau of Economic Research. 
Peruzzi, Michele, and Alessio Terzi. 2018. Growth Acceleration Strategies. Center for International Development Working Paper 91. Cambridge, MA: Harvard University. Prati, Alessandro, Massimiliano Gaetano Onorato, and Chris Papageorgiou. 2013. Which Reforms Work and under What Institutional Environment? Evidence from a New Data Set on Structural Reforms. Review of Economics and Statistics 95: 946-68.

Pritchett, Lant. 1996. Measuring Outward Orientation in LDCs: Can It Be Done? Journal of Development Economics 49: 307-35.

Pritchett, Lant, Kunal Sen, Sabyasachi Kar, and Selim Raihan. 2016. Trillions Gained and Lost: Estimating the Magnitude of Growth Episodes. Economic Modeling 55: 279-91.

Quinn, Dennis P. 1997. The Correlates of Change in International Financial Regulation. American Political Science Review 91: 531-51.

Rodrik, Dani. 1992. The Limits of Trade Policy Reform in Developing Countries. Journal of Economic Perspectives 6: 87-105.

Rodríguez, Francesco. 2007. Openness and Growth: What Have We Learned? In Growth Divergences: Explaining Differences in Economic Performance, ed. José Antonio O'Campo, K. S. Jomo, and Rob Vos. Chicago: University of Chicago Press.

Rodríguez, Francesco, and Dani Rodrik. 2000. Trade Policy and Growth: A Skeptic's Guide to the Cross-National Evidence. NBER Macroeconomic Annual 2000. Cambridge, MA: MIT Press.

Sachs, Jeffrey D., and Andrew Warner. 1995. Economic Reform and the Process of Global Integration. Brookings Papers on Economic Activity 1: 1-118.

Salinas, Gonzalo, and Ataman Aksoy. 2006. Growth before and after Trade Liberalization. Policy Research Working Paper 4062. Washington: World Bank.

Schor, Adriana. 2004. Heterogeneous Productivity Response to Tariff Reduction: Evidence from Brazilian Manufacturing Firms. Journal of Development Economics 75: 373-96.

Shatz, Howard J., and David G. Tarr. 2002. Exchange Rate Overvaluation and Trade Protection. In Development, Trade and the WTO: A Handbook, ed. Bernard Hoekman, Aaditya Mattoo, and Philip English. Washington: World Bank.

Sheu, Gloria. 2014. Price, Quality, and Variety: Measuring Gains from Trade in Differentiated Products. American Economic Journal: Applied Economics 6: 66-89. 
Srinivasan, T.N., and Jagadish Bhagwati. 2001. Outward-Orientation and Development: Are Revisionists Right? In Trade, Development and Political Economy: Essays in Honour of Anne O. Krueger, ed. Deepak Lal and Richard H. Snape, 3-26. New York: Palgrave.

Topalova, Petia, and Amit K. Khandelwal. 2011. Trade Liberalization and Firm Productivity: The Case of India. Review of Economics and Statistics 93: 995-1009.

Tovar, Jorge. 2012. Consumer Welfare and Trade Liberalization: Evidence from the Car Industry in Colombia. World Development 40: 808-20.

Wacziarg, Romain, and Karen Horn Welch. 2008. Trade Liberalization and Growth: New Evidence. World Bank Economic Review 22: 187-231.

Warner, Andrew. 2003. Once More into the Breach: Economic Growth and Integration. Working Paper 34. Washington: Center for Global Development.

Wei, Shang-Jin, and Zhiwei Zhang. 2007. Collateral Damage: Exchange Control and International Trade. Journal of International Money and Finance 26: 841-63.

Wei, Shang-Jin, and Zhiwei Zhang. 2010. Do External Interventions Work? The Case of Trade Reform Conditions in IMF Supported Programs. Journal of Development Economics 92: $71-81$.

Westphal, Larry E. 1990. Industrial Policy in an Export-Propelled Economy: Lessons from South Korea's Experience. Journal of Economic Perspectives 4: 41-59.

Williamson, John. 1994. The Political Economy of Policy Reform. Washington: Peterson Institute for International Economics.

Winters, L. Alan. 2004. Trade Liberalisation and Economic Performance: An Overview. Economic Journal 114: F4-F21.

Winters, L. Alan, and Antonio Martuscelli. 2014. Trade Liberalisation and Poverty: What Have We Learned in a Decade? Annual Review of Resource Economics 6: 493-512.

Winters, L. Alan, and Andrew Masters. 2013. Openness and Growth: Still an Open Question? Journal of International Development 25: 1061-70.

World Bank. 2001. Global Economic Prospects and the Developing Countries. Washington. Yanikkaya, Halit. 2003. Trade Openness and Economic Growth: A Cross-Country Empirical Investigation. Journal of Development Economics 72: 57-89. 
Figure 1 Number of countries undertaking trade reforms, 1960-2001

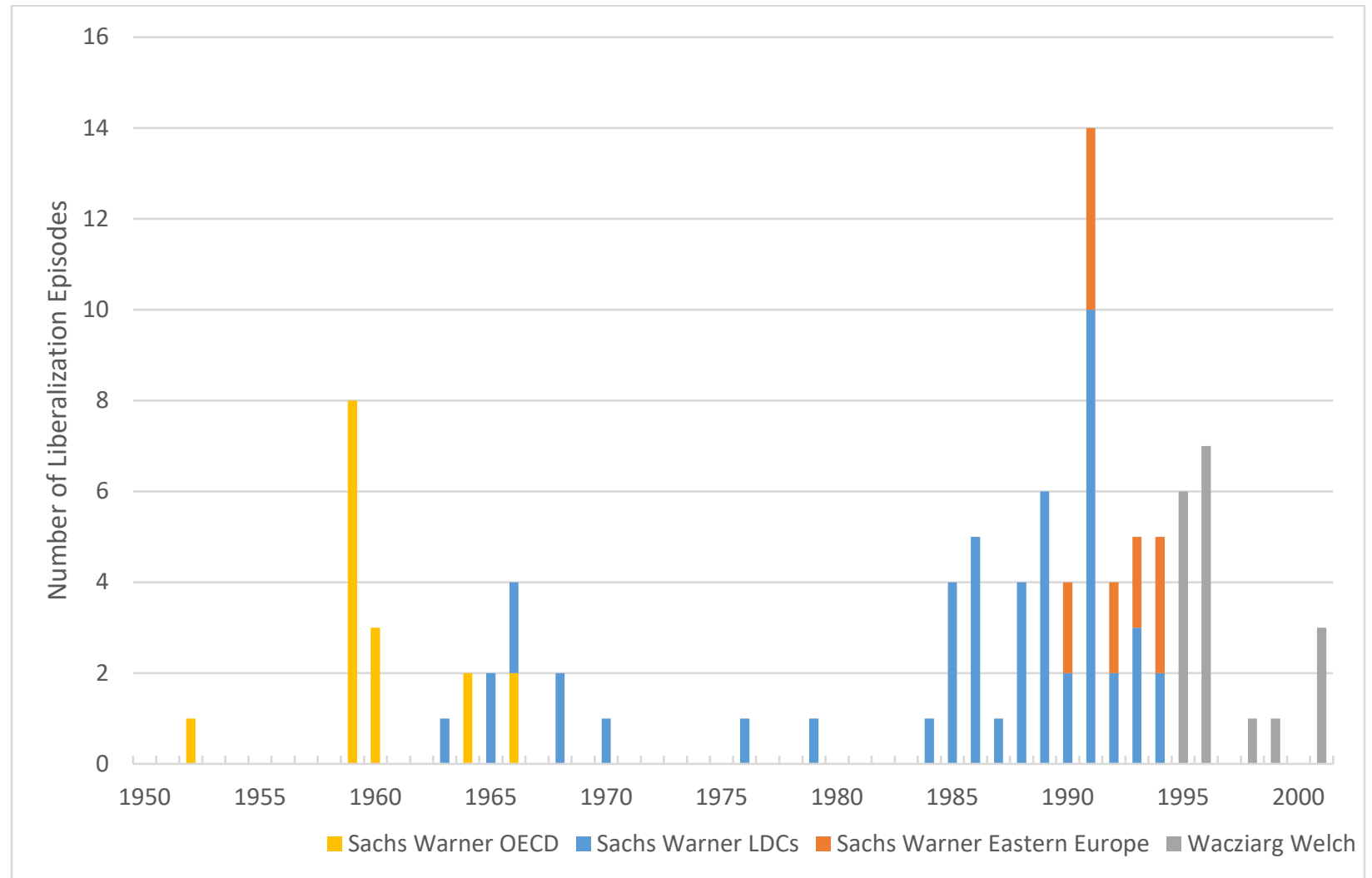

Sources: Sachs and Warner (1995); Wacziarg and Welch (2008). 
Figure 2 Average unweighted tariff rate in developed and developing countries, 1980-2010

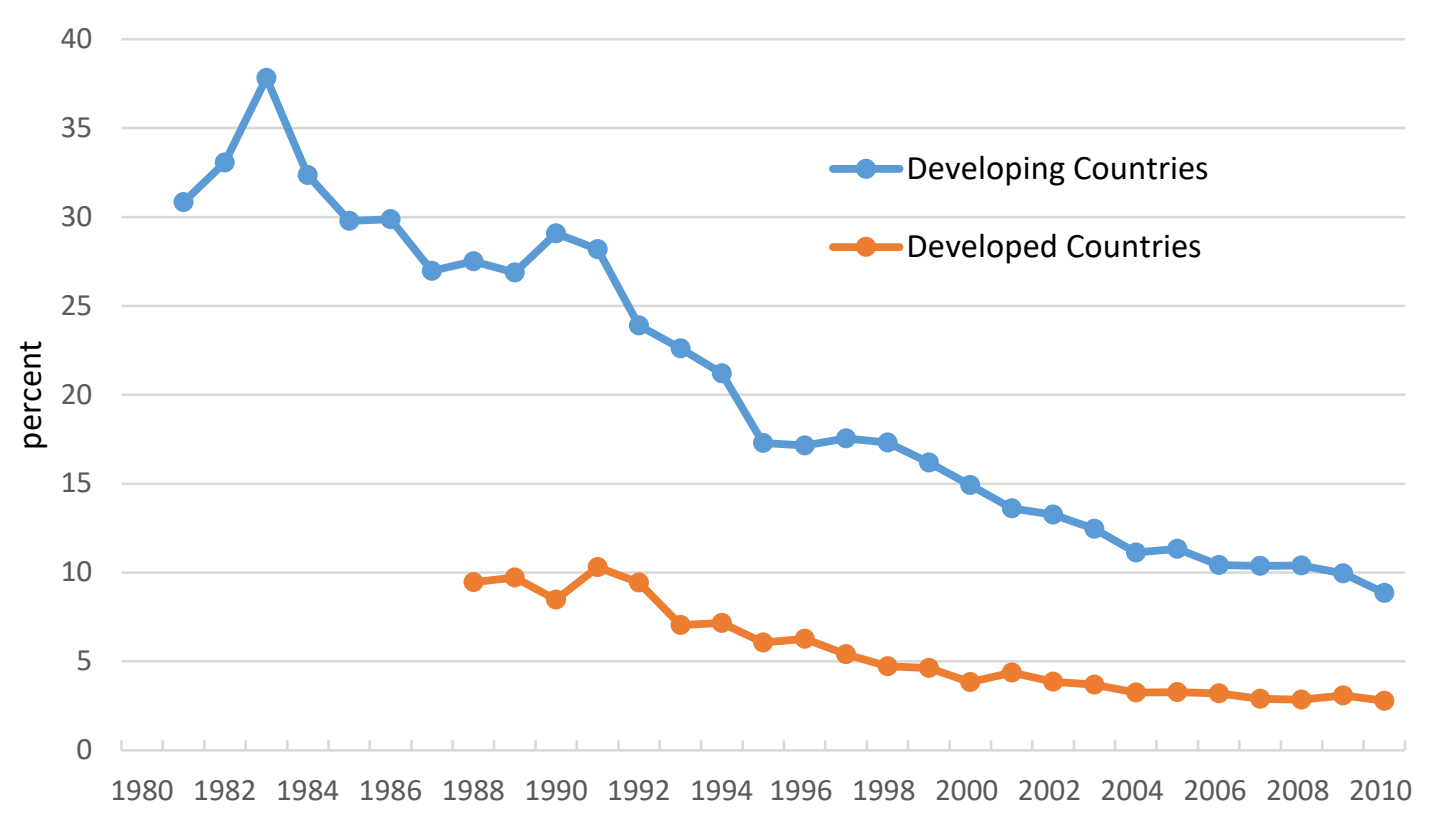

Source: World Bank Data on Trade and Import Barriers, http://siteresources.worldbank.org/INTRES/Resources/469232-1107449512766/tar2010.xls. 
Figure 3 Average unweighted import tariffs, by region, 1980-98

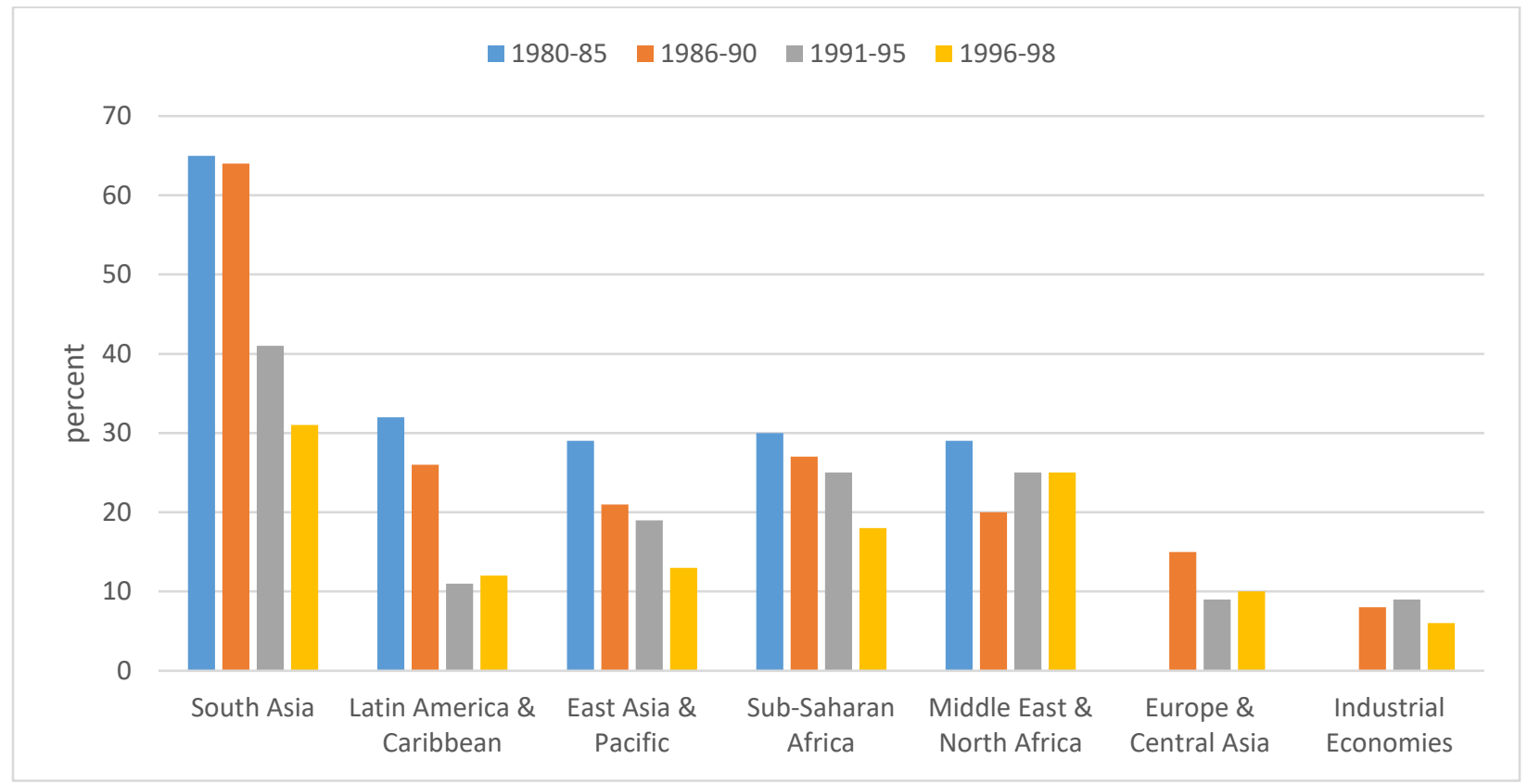

Source: World Bank (2001, 53). 
Figure 4 Percent share of countries imposing export surrender requirements or setting nonunified exchange rates

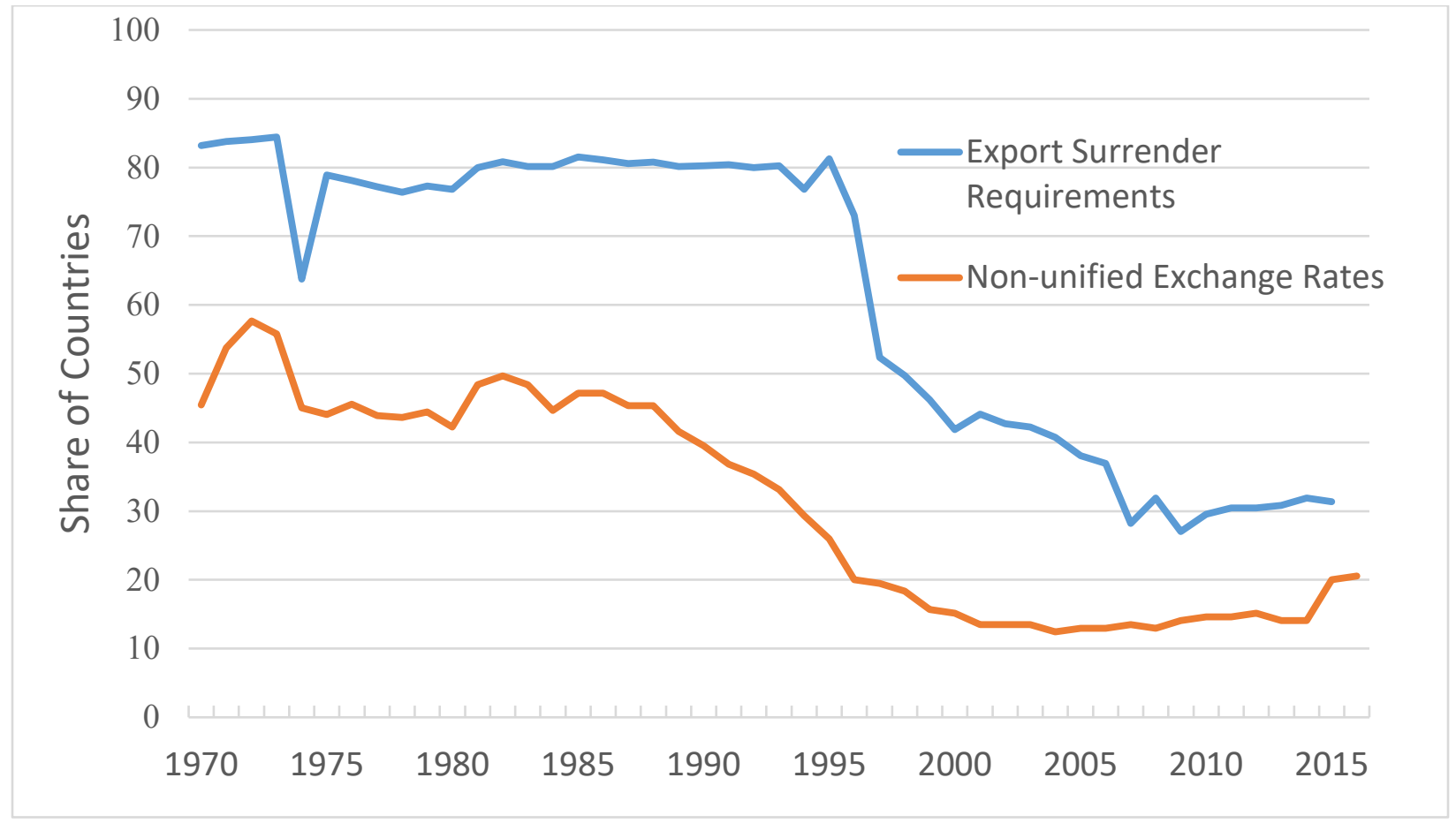

Sources: Nonunified exchange rates are from Ilzetzki, Reinhart, and Rogoff (2017); export surrender requirements are from IMF (various years). 
Table 1 Selected studies of trade reform and economic growth

\begin{tabular}{|c|c|c|c|c|}
\hline Study & Period & Policy indicator & Sample size & Main finding \\
\hline \multicolumn{5}{|c|}{ Growth regressions } \\
\hline $\begin{array}{l}\text { Greenaway, Morgan, } \\
\text { and Wright (2002) }\end{array}$ & $1975-93$ & $\begin{array}{l}\text { Various dichotomous } \\
\text { indicators }\end{array}$ & $\begin{array}{l}69 \text { developing } \\
\text { countries }\end{array}$ & $\begin{array}{l}\approx+2.7 \text { percentage point } \\
\text { increase in growth }\end{array}$ \\
\hline $\begin{array}{l}\text { Salinas and Aksoy } \\
\text { (2006) }\end{array}$ & $\begin{array}{l}1970- \\
2004\end{array}$ & World Bank episodes & $\begin{array}{l}39 \text { developing } \\
\text { countries }\end{array}$ & $\begin{array}{l}\approx+1.2 \text { percentage point } \\
\text { increase in growth }\end{array}$ \\
\hline $\begin{array}{l}\text { Wacziarg and Welch } \\
\text { (2008) }\end{array}$ & $1950-98$ & $\begin{array}{l}\text { Updated Sachs-Warner } \\
\text { indicator }\end{array}$ & $\approx 133$ countries & $\begin{array}{l}\approx+1.4 \text { percentage point } \\
\text { increase in growth }\end{array}$ \\
\hline $\begin{array}{l}\text { Falvey, Foster, and } \\
\text { Greenaway (2012) }\end{array}$ & $\begin{array}{l}1970- \\
2003\end{array}$ & $\begin{array}{l}\text { Wacziarg-Welch } \\
\text { indicator }\end{array}$ & $\begin{array}{l}39 \text { developing } \\
\text { countries }\end{array}$ & $\begin{array}{l}\approx+1.8 \text { percentage point } \\
\text { increase in growth }\end{array}$ \\
\hline $\begin{array}{l}\text { Falvey, Foster- } \\
\text { McGregor, and } \\
\text { Khalid (2013) }\end{array}$ & $\begin{array}{l}1970- \\
2005\end{array}$ & $\begin{array}{l}\text { Wacziarg-Welch } \\
\text { indicator }\end{array}$ & $\begin{array}{l}\approx 50 \text { developing } \\
\text { countries }\end{array}$ & $\begin{array}{l}\approx+1.7 \text { percentage point } \\
\text { increase in growth }\end{array}$ \\
\hline $\begin{array}{l}\text { Estevadeordal and } \\
\text { Taylor (2013) }\end{array}$ & $\begin{array}{l}1975- \\
2004\end{array}$ & $\begin{array}{l}\text { Average import tariff } \\
\text { (aggregate, } \\
\text { disaggregated) }\end{array}$ & $\begin{array}{l}\approx 44 \text { developed and } \\
\text { developing } \\
\text { countries }\end{array}$ & $\begin{array}{l}\approx+1 \text { percentage point } \\
\text { increase in growth, } \\
\text { income } 15-20 \text { percent } \\
\text { higher after } 20 \text { years }\end{array}$ \\
\hline $\begin{array}{l}\text { Feyrer and Irwin } \\
(2019)\end{array}$ & $\begin{array}{l}1950- \\
2015\end{array}$ & $\begin{array}{l}\text { Updated Wacziarg- } \\
\text { Welch, current account } \\
\text { openness, other } \\
\text { measures }\end{array}$ & $\approx 125$ countries & $\begin{array}{l}\text { Income } \approx 10-20 \text { percent } \\
\text { higher after } 5-10 \text { years }\end{array}$ \\
\hline \multicolumn{5}{|c|}{ Synthetic control } \\
\hline $\begin{array}{l}\text { Billmeier and } \\
\text { Nannicini (2013) }\end{array}$ & $\begin{array}{l}1963- \\
2005\end{array}$ & $\begin{array}{l}\text { Wacziarg-Welch } \\
\text { indicator }\end{array}$ & $\begin{array}{l}30 \text { developing- } \\
\text { country cases }\end{array}$ & $\begin{array}{l}\text { Positive but } \\
\text { heterogeneous effect of } \\
\text { trade reform on growth }\end{array}$ \\
\hline $\begin{array}{l}\text { Billmeier and } \\
\text { Nannicini (2011) }\end{array}$ & $\begin{array}{l}1993- \\
2005\end{array}$ & $\begin{array}{l}\text { Wacziarg-Welch } \\
\text { indicator }\end{array}$ & $\begin{array}{l}5 \text { transition } \\
\text { economies }\end{array}$ & $\begin{array}{l}\text { Positive but } \\
\text { heterogeneous effect of } \\
\text { trade reform on growth }\end{array}$ \\
\hline \multicolumn{5}{|c|}{$\begin{array}{c}\text { Country study } \\
\end{array}$} \\
\hline $\begin{array}{l}\text { Connolly and Yi } \\
\text { (2015) }\end{array}$ & $1962-89$ & $\begin{array}{l}\text { Tariffs and quantitative } \\
\text { restrictions }\end{array}$ & South Korea & $\begin{array}{l}\text { Tariff reductions } \\
\text { explain } 17 \text { percent of } \\
\text { Korea's catchup }\end{array}$ \\
\hline
\end{tabular}


Table 2 Selected studies of trade reform and industry productivity

\begin{tabular}{|c|c|c|c|}
\hline Country/study & Period & $\begin{array}{l}\text { Measure of } \\
\text { productivity }\end{array}$ & Main finding \\
\hline \multicolumn{4}{|l|}{ Chile } \\
\hline Pavcnik (2002) & $1979-86$ & $\begin{array}{l}\text { Plant total factor } \\
\text { productivity (TFP) } \\
\text { (revenue) }\end{array}$ & $\begin{array}{l}\text { The productivity of the import-competing } \\
\text { sector was 3-10 percent higher than the } \\
\text { productivity of the nontraded goods } \\
\text { sector. }\end{array}$ \\
\hline $\begin{array}{l}\text { Kasahara and Rodrigue } \\
(2008)\end{array}$ & 1979-96 & Plant TFP (revenue) & $\begin{array}{l}\text { Imported intermediates boosted } \\
\text { productivity } 2.6 \text { percent. }\end{array}$ \\
\hline \multicolumn{4}{|l|}{ Colombia } \\
\hline Fernandes (2007) & $1977-91$ & Plant TFP (revenue) & $\begin{array}{l}\text { A } 10 \text { percentage point reduction in tariffs } \\
\text { increased TFP by } 0.8-1.2 \text { percent in } \\
\text { affected industries. }\end{array}$ \\
\hline \multicolumn{4}{|l|}{ Indonesia } \\
\hline Amiti and Konings (2007) & $\begin{array}{l}1991- \\
2001\end{array}$ & Plant TFP (revenue) & $\begin{array}{l}\text { A } 10 \text { percentage point reduction in input } \\
\text { tariffs was associated with a } 12 \text { percent } \\
\text { increase in TFP. }\end{array}$ \\
\hline \multicolumn{4}{|l|}{ India } \\
\hline $\begin{array}{l}\text { Topalova and Khandelwal } \\
\text { (2011) }\end{array}$ & $\begin{array}{l}1987- \\
2001\end{array}$ & Plant TFP (revenue) & $\begin{array}{l}\text { A reduction in final goods tariffs } \\
\text { increased TFP by } 1.7 \text { percent. A } \\
\text { reduction in input tariffs increased it by } \\
10.6 \text { percent. }\end{array}$ \\
\hline Goldberg et al. (2010) & 1987-97 & Plant TFP (revenue) & $\begin{array}{l}\text { A reduction in input tariffs increased } \\
\text { product scope; new imported varieties } \\
\text { reduced the price index for intermediate } \\
\text { goods by } 4.7 \text { percent a year. }\end{array}$ \\
\hline \multicolumn{4}{|r|}{ O } \\
\hline Brandt et al. (2017) & $\begin{array}{l}1994- \\
2007\end{array}$ & Plant TFP (revenue) & $\begin{array}{l}\text { A reduction in final goods tariffs reduced } \\
\text { markups (procompetitive effect); a } 1 \\
\text { percentage point reduction in input tariffs } \\
\text { reduced output prices by } 1.6 \text { percent. }\end{array}$ \\
\hline Amiti et al. (2017) & $\begin{array}{l}1998- \\
2007\end{array}$ & Firm TFP (revenue) & $\begin{array}{l}\text { A reduction in input tariffs increased firm } \\
\text { TFP. }\end{array}$ \\
\hline
\end{tabular}

